\title{
THE FUNDAMENTAL IMPORTANCE OF BASIC SCIENCE: EXAMPLES OF HIGH-IMPACT DISCOVERIES FROM AN INTERNATIONAL CHEMISTRY NETWORK
}

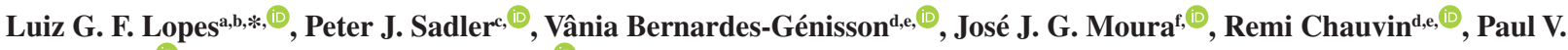

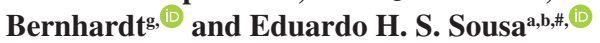 \\ ${ }^{a}$ Departamento de Química Orgânica e Inorgânica, Universidade Federal do Ceará, 60455-760 Fortaleza - CE, Brasil \\ 'Instituto Nacional de Ciência e Tecnologia em Tuberculose, 90160-091 Porto Alegre - RS, Brasil \\ 'Department of Chemistry, University of Warwick, Gibbet Hill Road, Coventry CV4 7AL, United Kingdom \\ ${ }^{\mathrm{d}}$ Laboratoire de Chimie de Coordination, LCC, CNRS, UPR 8241, 205 Route de Narbonne, BP 44099, F-31077 Toulouse, Cedex 4, \\ France \\ eUniversité de Toulouse, Université Paul Sabatier, UPS, 118 Route de Narbonne, F-31062, Toulouse, Cedex 9, France \\ fDepartamento de Química, Faculdade de Ciências e Tecnologia, Universidade Nova de Lisboa, 2829-516 Caparica, Portugal \\ ${ }^{\mathrm{g}}$ School of Chemistry and Molecular Biosciences, The University of Queensland, Brisbane - QLD, 4072, Australia
}

Recebido em 23/03/2020; aceito em 20/05/2020; publicado na web em 06/07/2020

\begin{abstract}
During the last 150 years or more, society has witnessed many key scientific discoveries and inventions, which have dramatically improved not only our quality of life, but our lifespan. However, the motivation of scientists to provide scientific advances has generally not been the achievement of these goals, but mainly driven by research curiosity. Fundamental scientific studies, also known as basic science, have paved the way to a society of knowledge by means of continuously evolving education systems, and have led to applied science and technological breakthroughs changing the World. However, without basic science such life-changing advances would not happen, which is poorly understood by the society. Having this in mind, chemists and biochemists working in a chemistry network highlight here examples of how basic science has played a crucial role and led to major breakthroughs. In seven short stories, the authors describe cases and historical events where basic research discoveries have advanced science, and opened avenues for future achievements. Investment in basic science is crucial for a nation's health and wealth. The support of scientists driven by curiosity ultimately can benefit the whole of society, not only in innovative products, but also in the improvement of the understanding of our own lives.
\end{abstract}

Keyword: basic science; applied science; chemistry; epistemology.

\section{INTRODUCTION}

Science is knowledge, and scientific research generates new knowledge. This new knowledge improves human health and wellbeing, in particular health by improving the detection and treatment of diseases, the quality of our food, and our interaction with the environment.

The most fundamental scientific knowledge is the basis of what we call basic scientific research. Often such research does not set out to solve a given problem, but to explore new problems and inspire others. It is often many years, even decades or more, before the value of basic scientific research is appreciated and recognisable, and widely-appreciated applications are generated.

The financial support of basic scientific investigations is a key investment for the future, which generates long-term major achievements. However, the value of basic research studies is not readily appreciated, neither by lay people, nor even by young students of science. Indeed, it is not always evident, even for highly trained scientists, that specific basic research will lead to breakthroughs. This may be, in part, the reason for the lack of enthusiastic support by governments. There is an increased call for the naming of potential "beneficiaries" (or a response to the "market"), and scientific agencies are even more pressed to show they are financing scientific projects that can generate a "useful" end product, very soon or in the near future, leading to support being prioritized for applied science. Even if this concern is fair, useful applications of basic science usually do

*e-mail: lopeslu@dqoi.ufc.br

\#alternative e-mail: eduardohss@dqoi.ufc.br not emerge without a solid basis from fundamental scientific studies. Applied research has a limited lifetime of new ideas, usually with only short-term benefits. Novel scientific breakthroughs are critical to feed and keep continuously generating future applied benefits. There is a well-trodden pathway along which basic science feeds applied science and technology. If basic science is not done, then, no major applications are likely to arise, just as a river will dry up if it is not fed with a source of water (ideas).

As an example, in 2019, a well-known forum took place in Brazil with scientific agencies of 45 Countries (Meeting of the Global Research Council), where they discussed the increasing expectation of delivering support to research with "societal or economic" impacts, and 18 principles were listed for that goal. ${ }^{1}$ Notably they reiterated a previous principle on the dynamic interplay between basic research and innovation that "focusing too much on short-term results will put the future seeds of innovation at risk". ${ }^{1}$

But what is indeed basic science and why should we (society) believe it must be adequately funded? Here we highlight reasons why society should invest money in basic investigations and emphasise how such investment can pay dividends for the whole of society.

It is also the job of scientists to convince sceptics of the value of their work, current examples including anti-vaccine and anti-climate change groups. Such anti-views are currently held globally in a range of countries, with the backing of social media. ${ }^{2-4}$ All of this, strongly supports the view that scientists must give priority to educating people at all levels, with increasing effort to communicate to society about science, with illustrative cases and facts about scientific knowledge. Fortunately, an increasing number of voices have emerged which 
better explain and advocate the scientific knowledge behind some key topics, and alert the society to their risks. ${ }^{5-10}$

Here, we tell 7 short stories to exemplify basic science and the actual impact it can have (or is expected to have) in our society. These randomly-chosen stories are close to the interest and scientific endeavors of the authors themselves. The authors have a common goal to work in scientific collaboration within a topic of bioinorganic chemistry, a field at the frontier of organic/inorganic chemistry, biology and medicine.

It is interesting to note that the authors are scientists from five different Countries (Brazil, Portugal, United Kingdom, France and Australia) and from three different continents (South America, Europe and Australia) sharing their excitement, stories, and views on the relevance of basic science, which makes this article a more global representation of ideas. What motivates scientists to do basic science is curiosity. Financing that may help to uncover what is not in front of our eyes, and lead to breakthroughs.

These stories are intended to illustrate how basic science is relevant not only to the advancement of our knowledge of Nature, but can lead to important contributions to society.

\section{HOW AN ATMOSPHERIC POLLUTANT (NITRIC OXIDE, NO) HAS EMERGED AS A KEY BIOLOGICAL MOLECULE IN HUMANS: FROM BASIC STUDIES TO THE DEVELOPMENT OF NOVEL MEDICINAL AGENTS BY LUIZ G. F. LOPES}

Cardiovascular diseases (CVD) are the leading cause of death worldwide, accounting for nearly 17.9 million people dying in each year, making up $32 \%$ of all global deaths (WHO). ${ }^{11}$ This type of disease is caused, mainly, by dysregulation of blood pressure like arterial hypertension. Blood pressure regulation is controlled by the endothelium-dependent relaxation factor (EDRF), which in the 80's was studied by Furchgott, Murad and Ignarro. These researchers concluded that EDRF was indeed the nitric oxide molecule, which would bind and stimulate the soluble guanylate cyclase enzyme. ${ }^{12}$ This discovery yielded the Nobel Prize for Physiology or Medicine in 1998 for these researchers.

After all basic studies carried out by these three researcher labs, among others, regarding the identity and action of the EDRF in endothelium function, it was possible to explain how nitric oxide (NO), a diatomic inorganic gas, known until that time as an air pollutant, could transmit chemical signals in the human body. Those studies brought up a true revolution in medicine, where NO has been involved in many key processes, and has an important role in cardiovascular disease treatment. Basic understanding of the reactivity of the NO molecule became essential to better understand its fate in the body and how to use it. In this field, sodium nitroprusside (SNP), $\mathrm{Na}_{2}\left[\mathrm{Fe}(\mathrm{CN})_{5} \mathrm{NO}\right]$, an iron-based NO donor molecule, has been used clinically to lower blood pressure in cardiac surgery, hypertensive crises, heart failure, vascular surgery, pediatric surgery, and other acute hemodynamic applications. ${ }^{13}$ SNP is indeed a prodrug, which, upon administration into the patient, reacts with sulfhydryl groups of biomolecules in the erythrocytes, albumin, and other proteins to release NO. ${ }^{14}$

The use of SNP is necessary in certain cases when a patient needs to quickly lower their blood pressure. This metal-based compound was discovered in 1851 by Playfair when he was studying the reactions of potassium salts containing cyanoferrates with nitrous acid. ${ }^{15}$ Interestingly, its use in patients was first proposed by Johnson in $1922,{ }^{16}$ and was used with safety and efficacy to lower the blood pressure in severely hypertensive patients in $1955,{ }^{17}$ many decades before any knowledge of the biological role of NO. However, despite the proved efficacy of this prodrug, its use needs to be controlled due to toxicity. SNP, in vivo, reacts with oxyhemoglobin to form methemoglobin leading to release of $\mathrm{NO}$ and cyanide, ${ }^{18,19}$ a poisonous molecule, which can be accumulated in the body making it toxic to cerebral endothelial cells, ${ }^{20}$ hepatocytes, ${ }^{21}$ and neural cell lines, ${ }^{22}$ due to generation of reactive oxygen species inducing cell death by apoptosis. ${ }^{13}$ So, new strategies to overcome cyanide toxicity or new non-cyanide-based NO donor compounds needed to be developed. However, to reach this goal it is necessary to have a series of basic understanding of the properties of a new compound enabling a rational design, where its final products are less toxic, rates of NO release are adjustable as well as to prepare stable molecules.

Having all of that in mind, our group has been working mainly on preparing new non-cyanide-based metallo-nitrosyl species as NO (and/or HNO) donors, employing mostly ruthenium and iron metal centers. During these years, we have learned from many basic studies how to modulate the reactivity and stability of metal complex aiming to develop better donors with attractive biological properties. Recently, we have also developed a strategy to minimize the cyanide release from SNP as well..$^{23}$

In the first case, we have prepared several nitrosyl metal complexes, which can release NO and/or HNO selectively upon chemical and/or electrochemical reduction of the $\left[\mathrm{M}^{\mathrm{II}}-\mathrm{NO}^{+}\right]$ moiety or even by light irradiation. These compounds have shown great promise as new candidates of non-cyanide-based NO/HNO releasers, and, consequently, we have observed a series of exciting biological properties such as vasodilation activity, ${ }^{24}$ neuroprotection during ischemia/reperfusion in the brain, ${ }^{25}$ anti-Chagas disease, ${ }^{26}$ anti-paracoccidioidomycosis activities, ${ }^{27}$ gastric protection, ${ }^{28}$ antileishmanial activity, ${ }^{29,}{ }^{30}$ anti-angiogenesis activity ${ }^{31}$ and analgesic effects, ${ }^{32}$ among others. ${ }^{33-36}$ Some of these compounds have also shown low cytotoxicity, exhibiting a high lethal dose in mice, ${ }^{26,34}$ stimulating further steps. Beyond our own compounds, many other groups in Brazil and around the World have shown the potential of NO donors in medicine, where exciting products have advanced such as socks for diabetics, ${ }^{37}$ bandages for organ preservation and wound healing among others. ${ }^{38-40}$

In the second strategy, we recently incorporated sodium nitroprusside into silica nanoparticles (MPSi-NP) and evaluated its ability to preserve vasodilation properties but decreasing cyanide release in biological fluids. ${ }^{23}$ This new system showed similar efficiency in promoting vasodilation compared with free SNP, but with a remarkably lower cytotoxicity. Our direct measurements of cyanide release supported an expressive decrease in comparison to free SNP. So, this seems to be a worthy strategy to further pursue to better overcome cyanide toxicity of SNP. All of these achievements and future expected products were developed due to our understanding of the fundamental properties of these compounds through basic research investigation, and more is coming.

\section{YEARS OF THE PERIODIC TABLE: THE ELEMENTS OF LIFE AND MEDICINES - THE IMPACT OF BASIC CHEMICAL RESEARCH ON HUMAN HEALTH BY PETER J. SADLER}

\section{Nullius in verba ('Take nobody's word for it')}

'Nullius in verba' is the motto of the Royal Society (of London), the UK's National Academy principally founded by the scientist John Wilkins, of which I am a Fellow. It was founded as a learned society in 1660, and from 1963 onwards became known as 'The Royal Society of London for Improving Natural Knowledge'. Founding Fellows included Christopher Wren, the architect of St Paul's Cathedral, John Wilkins, an Anglican clergyman, natural philosopher and author, and 
Robert Boyle, a pioneer of modern chemistry (Boyle's Law for gases and early notion of "molecule"). ${ }^{41}$

Other well-known Fellows include Isaac Newton (1672), Charles Darwin (1839), Michael Faraday (1839), Dmitri Mendeleev (1892), Albert Einstein (1921), Dorothy Hodgkin (1947), Francis Crick (1959), and Stephen Hawking (1974).

The motto itself stresses the critical importance of scientific research - the acquisition of new knowledge: Fellows strive to verify all scientific statements by an appeal to facts determined by experiment- do not take anyone's word for them.
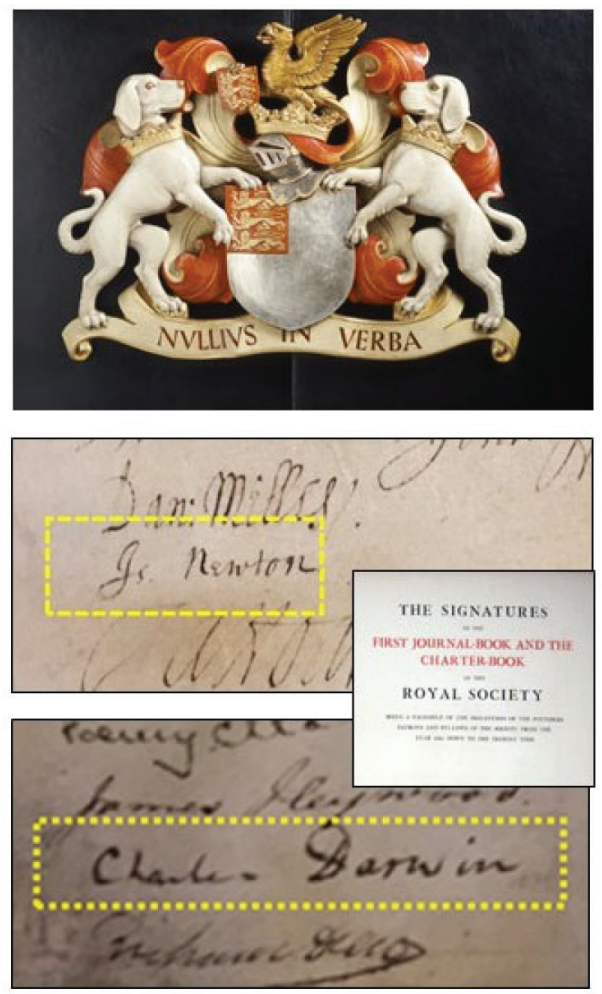

Figure 1. The crest of the Royal Society of London (@The Royal Society) bearing the motto 'Nullius in verba', together with an extract from the Charter Book signed by newly-elected fellows, and examples for Isaac Newton (1672) and Charles Darwin (1839). Even today, Fellows sign the book using a quill pen and black ink. Currently there are about 1,600 Fellows and Foreign Members; 52 Fellows and up to 10 Foreign Members are elected each year. Newton discovered the laws of gravity and motion, and invented calculus. Darwin's proposition that all living species have descended from common ancestors is now a fundamental scientific concept. After publication of his book "On the Origin of Species" in 1859, it took several decades before his views on natural selection as the basis of evolution were accepted. The crest is reproduced with permission from The Royal Society

The quest for new knowledge can perhaps be no more fundamental than establishing which of the 81 stable elements on earth are essential for a healthy life.

\section{Which elements are essential for human life?}

Dimitri Mendeleev created the periodic table as we know it today in 1869,151 years ago. He used the information he had about the relative atomic weights of the 63 elements known at that time to arrange them in a periodic order that reveals similarities in their chemical properties, and importantly predicted the existence of gallium, germanium, and scandium, elements which were then unknown, and technetium which did not exist on earth until 1937.
Today we have a periodic table of 118 elements. The heaviest stable element found on earth is bismuth, atomic number $Z=83$, but the lighter elements technetium $(Z=43)$, and promethium $(Z=61)$ are humanmade, leaving 81 elements which might be essential for our lives. The human-made creation of technetium in 1937 has unexpectedly led to major medical advances. Its radioactive isotope Tc-99m, a high energy gamma radiation emitter with a half-life of 6 hours, is used in over 10,000 hospitals worldwide to diagnose disease, comprising some 40 million procedures every year. ${ }^{42}$ Similarly, compounds of the rare earth element gadolinium discovered in 1880 , and once thought to be only of academic interest, were introduced into the clinic as contrast agents in Magnetic Resonance Imaging of the human body in 1983, and are now administered to over 30 million patients every year. ${ }^{43}$

Of the 81 stable elements, there is good evidence that 19 of them are essential for human health: $\mathrm{H}, \mathrm{C}, \mathrm{N}, \mathrm{O}, \mathrm{Na}, \mathrm{Mg}, \mathrm{P}, \mathrm{S}, \mathrm{Cl}, \mathrm{K}$, $\mathrm{Ca}, \mathrm{Mn}, \mathrm{Fe}, \mathrm{Co}, \mathrm{Cu}, \mathrm{Zn}, \mathrm{Se}, \mathrm{Mo}$, and I. Another 7 can be described as potentially essential: $\mathrm{F}, \mathrm{Si}, \mathrm{V}, \mathrm{Cr}, \mathrm{Ni}, \mathrm{Br}$ and $\mathrm{Sn}$. In total there is documented clinical and medical use of about 76 elements in a variety of compounds and other forms. Even radioactive elements find widespread use in the detection and treatment of diseases. ${ }^{44-46}$

I describe here briefly some of the basic research my research group and I have carried out recently in collaboration with Brazilian scientists: specifically Ana Gondim, Eduardo H. S. Sousa, Luiz Gonzaga de França Lopes, Catherine Teles, and Benildo S. Cavada from the Federal University of Ceará, Fortaleza, and Carolina Oliveira, and Victor Deflon at the Federal University of Uberlândia and University of São Paulo, and their colleagues. Visits to my lab in the UK have made very important contributions to our discoveries.

\section{Discovery of new medicines in Brazilian flora}

About $40 \%$ of prescription medicines used today are derived from plant compounds. These include Artemisinin, an antimalarial from the sweet wormwood plant, digitoxin, a cardiotonic (improves heart action) from floxgloves, etoposide, an antitumour agent from woodland mayapple plants, morphine, an analgesic from poppy seeds, quinine, an antimalarial from the bark of the cinchona tree, Taxol, an antitumour agent from the the bark of the yew tree, and rifampicin, an anti-tubercular drug extracted from a soil bacterium. The first mass-produced antibiotic Penicillin, is derived from Penicillium fungi.

Brazil has a rich diversity of plants with enormous potential for the discovery of new medicines. My colleagues at the Federal University of Ceará have isolated and characterised a lectin protein from seeds of the Dioclea lasiocarpa, a flowering plant from the pea family, collected from the northeast coast of Brazil. ${ }^{47}$

Remarkably, we found that Dioclea lasiocarpa lectin protein, which contains calcium and manganese metal ions and binds strongly to sugar molecules, can kill human ovarian, lung, breast and prostate cancer cells at very low (nanomolar) doses. ${ }^{48}$ Lectins are often resistant to digestion and therefore candidates as oral drugs. Further research based on these promising initial findings might lead to a new anticancer drug with a novel mechanism of action that can combat resistance to treatment with current anticancer drugs.

In collaboration with Jan Balzarini and colleagues (Rega Institute for Medical Research, Leuven, Belgium), we further investigated the biological activity of 9 lectins extracted and purified from Northeastern Brazilian leguminous species and algae. ${ }^{49}$ Notably several of these lectins showed highly potent (nanomolar) activity when tested against a panel of 18 different viruses, including HIV and influenza viruses. These encouraging results suggest that Brazilian flora are a source of novel antiviral compounds with therapeutic potential, which might have potential for treating COVID-19 as well. 


\section{New approaches to cancer treatment}

The Nobel Prize in Physiology or Medicine 2019 was awarded jointly to William Kaelin, Peter Ratcliffe and Gregg Semenza for their discoveries of how cells sense and adapt to oxygen availability, and how oxygen levels affect cellular metabolism and physiological function. Some of their important discoveries were made over 25 years ago. ${ }^{50}$

A key protein for oxygen-sensing in our cells is the hypoxiainducible factor (HIF). Normal oxygen levels control rapid HIF-1 $\alpha$ degradation with the help of oxygen-sensitive enzymes (irondependent prolyl hydroxylases which add oxygen atoms to the protein). In hypoxia, HIF-1 $\alpha$ is protected from degradation and can bind to DNA and regulate gene expression.

HIF- $1 \alpha$ appears to contribute to the mechanism by which cancer cells grow rapidly even under the hypoxic conditions in tumours. ${ }^{51}$ HIF- $1 \alpha$ is stabilised by nitric oxide (NO), a reactive small molecule which promotes dilatation of blood vessels and blood flow. In contrast, the protonated form of reduced $\mathrm{NO}$ (HNO), which has the same number of electrons as $\mathrm{O}_{2}$ (isoelectronic), promotes degradation. The ruthenium coordination complex $\left[\mathrm{Ru}(\mathrm{bpy})_{2}\left(\mathrm{SO}_{3}\right)(\mathrm{NO})\right]^{+}$can liberate $\mathrm{HNO}$ on reaction with glutathione (which is abundant in cancer cells), and has potential as an anti-angiogenesis anticancer agent, reducing the growth of new blood vessels which tumours need to grow. ${ }^{31}$ It is interesting to note that ruthenium is $c a$. 20-fold cheaper than platinum, and so its cost is not an economic restraint on its use in medicine. Beyond that, in general, ruthenium compounds are less toxic than platinum, but this property does not depend only on the metal itself, but also on its oxidation state and the surrounding ligands. This issue can be illustrated using the example of cisplatin (cis- $\left.\left[\mathrm{Pt}\left(\mathrm{NH}_{3}\right)_{2} \mathrm{Cl}_{2}\right]\right)$, which is toxic to cancer cells, but its isomer transplatin (trans-[Pt( $\left.\left.\left(\mathrm{NH}_{3}\right)_{2} \mathrm{Cl}_{2}\right]\right)$ is not, while the $\mathrm{Pt}(\mathrm{II})$ tetra-ammine complex of $\left[\mathrm{Pt}\left(\mathrm{NH}_{3}\right)_{4}\right]^{2+}$ has a very low toxicity.

There is potential too for medical use of osmium the heaviest congener in group 8 (Fe, Ru and Os) of the periodic table. So far, the medicinal chemistry of osmium has been little explored. My research lab has recently discovered organo-osmium complexes which are more potent toward cancer cells than the clinical drug cisplatin. ${ }^{52}$

\section{Platinum compounds - the most widely used drugs for cancer treatment}

Platinum compounds are currently used in about $50 \%$ of all chemotherapy treatments for cancer. The serendipitous discovery of the anticancer activity of platinum compounds provides an example of how basic research can unexpectedly lead to applications which benefit society, in this case curing cancer. The anticancer drug cisplatin was unexpectedly discovered in the laboratory of physicist Barnett Rosenberg at Michigan State University in the late 1960s, whilst he was studying the effects of electric fields on (bacterial) cell division. ${ }^{53}$ The passage from an academic laboratory bench to the clinic is slow- it took 10 years for platinum, and continued investment of funding during such development is essential. From this discovery, second generation platinum drugs have followed, carboplatin and oxaliplatin, and others. Oxaliplatin was first discovered in 1976, but took over 20 years to reach clinical approval, before becoming a billion-dollar drug.

Now my research group has discovered light-activated platinum anticancer drugs with potential for treating resistant cancers with reduced side effects. ${ }^{54}$

\section{Adventures with palladium}

Platinum shares similar chemistry with palladium, another precious metal which is above it in group 10 of the periodic table.
Despite the common flat, square-planar shapes of both $\mathrm{Pt}^{2+}$ and $\mathrm{Pd}^{2+}$, it is difficult to design active $\mathrm{Pd}^{2+}$ anticancer complexes. They react too quickly; they exchange their bound ligands before they reach target sites cells. However, we have found that this chemistry can be drastically changed by wrapping chelating ligands around $\mathrm{Pd}^{2+}$.

New palladium complexes with thiosemicarbazonate ligands derived from pyrene exhibit potent antiproliferative activity against human ovarian cancer cells. ${ }^{55}$ These complexes are potent inhibitors of the topoisomerase IB, an enzyme which controls DNA winding/ unwinding, with selectivity for cancer versus normal cells. These encouraging data may generate new drugs for combatting resistant cancers.

\section{WHEN BASIC RESEARCH CROSSED APPLIED RESEARCH: THE CASE OF TAXOL BY VANIA BERNARDES-GÉNISSON}

As professor of medicinal chemistry at the Faculty of Pharmacy of the University Paul Sabatier (Toulouse-France) and a research scientist, I have chosen to illustrate, in the following paragraphs, the importance of the basic research through an example that has had a deep impact both on a societal and personal level. I hope this case will help the reader to understand the difference between basic research and applied research.

In the 1980s, to build a new road in "Gif sur Yvette" (a French commune located twenty-four kilometers south-west of Paris), several yew trees were cut down. Quite opportunistically, Dr. Pierre Potier, pharmacist and researcher at CNRS (French National Center for Scientific Research), decided to collect them to isolate and identify the compounds naturally produced by this species ${ }^{56}$ For this, of course, financial support was needed. In our current politico-scientific context, in which governments are drastically reducing investments in basic research, one can ask who else would have wished to sponsor this work without actually knowing what could be found. Would you be willing to invest your money in this project and support the curiosity of this French researcher? This classical academic work, held at the "Natural Products CNRS Institute" (French public research institution), led to the discovery of a novel natural compound that immediately showed immense interest in the pharmacological field. Indeed, at the same period, Bristol Myers Squib (BMS), an American pharmaceutical company, was developing a new antitumor drug, called paclitaxel $\left(\right.$ Taxol ${ }^{\circledR}$, hereinafter referred as taxol) extracted from the bark of the Pacific yew. ${ }^{57}$ Despite the very promising results obtained with this compound during the clinical study phase, its development as a new anti-cancer drug was threatened for ecological reasons. Indeed, to isolate $25 \mathrm{~kg}$ of the new antitumor agent about 38,000 trees would have to have been cut down, which would raise alarming environmental issues associated to the particularly slow growth of this species. ${ }^{57}$ In addition, taxol exhibits a very complex molecular structure and the total synthesis of this product at an industrial laboratory for a world scale manufacturing could not be considered. Indeed, the first total syntheses of taxol were only reported independently by K. C. Nicolaou ${ }^{58}$ and R. A. Holton ${ }^{59,60}$ in 1994, more than 20 years after the first isolation of the natural product. ${ }^{61}$ Furthermore, these synthetic routes involved about 40 steps and had an overall yield well below $1 \%$. So, by lack of material, it would not be possible to continue the clinical development of this promising antitumor compound and the study would be stopped. It was at this point that Dr. Potier's story crossed that of BMS. Indeed, Dr. Potier's team had found in the thorns of the yews of Gif sur Yvette, a new natural product (10-deacetylbaccatin III, Figure 2) with the same basic framework as that of the antitumor taxol, studied by BMS, although devoid of any significant anticancer activity. A prominent potential interest of this compound was that it could be extracted from 


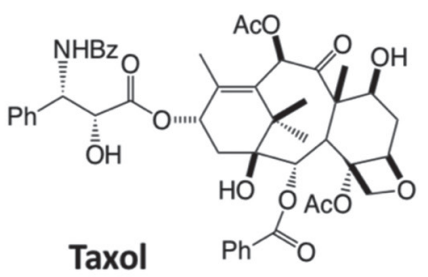

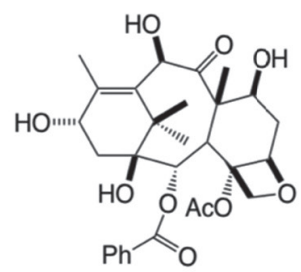

10-deacetylbaccatin III

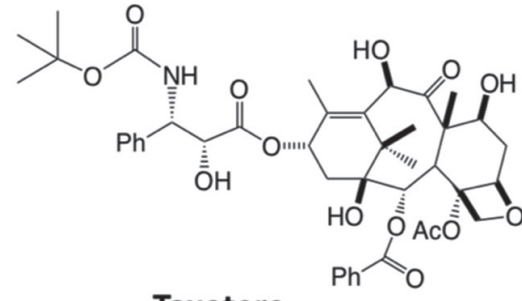

Taxotere

Figure 2. Structures of the natural products taxol and 10-deacetylbaccatin III and of the non-natural compound taxotere

the renewable thorns without causing death of the tree. In addition, all that was missing by comparison to taxol was only a small side chain with two stereogenic centers of well-defined configurations. However, anchoring of the side chain to the natural basic framework was essential for the anticancer activity. It was thanks to previous works carried out by notable researchers, ${ }^{62-64}$ who wanted only to deepen their knowledge in fundamental organic chemistry (stereochemistry, asymmetric synthesis, protecting groups, total synthesis of natural products) without worrying about whether their discoveries would have immediate benefits for the society, that the synthesis of this lateral chain respecting the same threedimensional structure as that of the natural product and its coupling with the natural framework (deacetylbaccatin III) were achieved within a suitable time span allowing the clinical development of taxol.

This is an interesting case, where without the basic research on organic synthesis, the preparation of taxol and even that of its cousin docetaxel (Taxotere ${ }^{\circledR}$ developed by Rhône Poulenc, hereinafter referred as taxotere, Figure 2$)^{65}$ which is in fact a chemical precursor of taxol serendipitously discovered by the Potier's team, would not have been possible and many women around the world, including myself, could not have benefited from these drugs in breast cancer treatment.

The taxol story is so just one of the cases one can choose to illustrate the importance of fundamental research in the discovery of new drugs. In fact, a large number of drugs have been discovered "by chance" thanks to the curiosity and interest of researchers in basic disciplines such as for example the microbiology, organic chemistry and others. ${ }^{66}$

Currently, I am developing research focused on the understanding of the activation mechanism of anti-tuberculosis prodrugs like: isoniazid, ${ }^{67,68}$ pyrazinamide ${ }^{69}$ and ethionamide. ${ }^{70,71}$ These drugs, although known and used in clinics for more than sixty years, still hide certain secrets related to their active metabolites, their mode of action and their toxicity. Thanks to fundamental research, we hope that better knowledge of the behavior of these molecules will be able to provide key elements allowing, in the future, the design and the synthesis of anti-tuberculosis agents more effective, safer and active on wild and resistant Mycobacterium tuberculosis strains to prevent the resurgence of tuberculosis worldwide.

\section{FROM BASIC TO APPLIED RESEARCH, FROM BACTERIA TO HUMANS BY JOSÉ J. G. MOURA}

Our research group has worked for several years on fundamental studies on the role of metal ions in biology, in order to reveal structural-function relations in proteins and enzymes involved in crucial pathways covering areas such as energy, health, agriculture and the environment. Here, we tell a story of one of these cases. This all starts in the 1970s and is a good example of how basic research may have impact in an applied context. In those days, we detected a "strange red protein band" in the chromatographic purification steps of a bacterial extract obtained from the biomass of a sulfate reducing bacterium, Desulfovibrio gigas (Dg) (a bacterium with impact in environmental problems (accumulation of sulfide) and energetic interests (hydrogen production and association with methanogens)). ${ }^{72}$ The isolated protein was shown after biochemical/chemical methods and spectroscopic tools to contain molybdenum (Mo), to our big surprise. $^{73}$

Molybdenum-containing enzymes play a major role in biological systems and have been found in two distinct forms: a complex [Fe-Mo-S] metallic cluster, which occurs in nitrogenases (a primordial enzyme in the $\mathrm{N}$-cycle involved in nitrogen fixation to ammonia), and a mononuclear Mo (or W) atom associated with one or two pyranopterin-ene-1,2-dithiolate cofactors [Mocofactor or Moco], as in Xanthine oxidase, Aldehyde oxidase and Sulfite oxidase. ${ }^{74-77}$

Extraction of the metal co-factor and the presence of Fe/S centers showed that the isolated red protein had unexpected analogies with xanthine oxidase a relevant enzyme in human metabolism of purines, and related with health problems (i.e., gout disease). Then, we could show that this bacterial protein had an aldehyde oxidase activity, and reactivity to similar substrates as xanthine oxidase (these group of enzymes are quite promiscuous in terms of metabolites accepted). ${ }^{78,79}$ The lack of 3D structures of this group of enzymes (the so-called mononuclear Mo-enzymes) limited the proposal of mechanisms. In 1995, the structure of the first mononuclear Mo-enzyme (Dg Aldehyde oxido-reductase) was solved and structural details of the active site reported..$^{80,81}$ The ligands around the metal were firmly determined and a water molecule in the vicinity of the metal site identified as the one involved in $\mathrm{O}$ atom insertion in the substrate (conversion of aldehyde to carboxylic acid). Inhibitors of this activity were also studied identifying the Mo-site as a target of drugs. Then, the bacterial structure was used extensively as a model until the structure of the human enzyme (Xanthine oxidase) was finally solved in $2000 .^{82}$

\section{Structural features of Dg Aldehyde oxido-reductase ${ }^{80,81}$}

The aldehyde oxido-reductase Desulfovibrio gigas is a member of the xanthine oxidase protein family, as mentioned before, and its 3D structure has been analyzed at high resolution, a relevant step for the understanding of mechanistic aspects (substrate and inhibitors interactions). The protein, a homodimer, catalyzes the oxidation of aldehydes to carboxylic acids. This protein has structural similarities to xanthine oxidase, contains ( $2 \mathrm{Fe}-2 \mathrm{~S}$ ) centers, lacking the domain that contains a flavin moiety, although it was recognized that a small flavodoxin participates in electron transfer (Figure 3).

The protein molecule is folded into four domains (the first two bind the iron sulfur clusters and the others the Moco). The Mo-site is deeply buried in the protein accessible through defined tunnel. The molybdenum is penta-coordinated with two dithiolene sulfur atoms of one molybdopterin (cofactor identified as pyronopterin cytosine dinucleotide $)^{73,74}$ and three oxygen ligands, of which one is presumably an oxo or one a sulfide group in the functional sulfo-form of the enzyme in analogy to xanthine oxidase.

Different EPR (X-band) molybdenum(V) were detected for Dg Aldehyde oxido-reductase with similarities to the inactive, and 
the physiologically significant signals develop within the enzyme turnover time scale (active forms) of Xanthine oxidase. These studies were complemented by CD measurements and advanced EPR spectroscopic studies revealing the presence of two types of [2Fe-2S] cores, named Fe/S I and Fe/S II centers. ${ }^{57} \mathrm{Fe}$-enriched Dg Aldehyde oxido-reductase enabled iron-sulfur-center site specific labeling, enhanced sensitivity for Mossbauer studies (an advantage of using bacteria with respect to mammalian systems). ${ }^{77}$

\section{Mechanism based structure}

The 3D structure of the Xanthine oxidase-related molybdenum-iron protein Aldehyde oxido-reductase isolated from Desulfovibrio gigas was analyzed in its desulfo-, sulfo-, oxidized, reduced, and alcoholbound forms at different resolutions. Bound inhibitory isopropanol in the inner compartment of the substrate-binding tunnel is a model for the reaction with aldehydes, and mechanistic details were proposed for the reaction, as well as modes of action of inhibitors (details of the proposed mechanism are indicated in the legend of Figure 3).

Aldehyde oxido-reductase activity has also been found in different sulfate reducing organisms. We also obtained complete biochemical, enzymatic and structural data for the Aldehyde oxido-reductase isolated from $D$. desulfuricans ATCC 27774, a sulfate reducer that can use nitrate as an alternative respiratory substrate to sulfate. ${ }^{83,84}$

Relevance of a Bacterial enzyme to Human Heath: implications of fundamental research in applied research (i.e., human health) $)^{85-90}$

The lack of fine structural information on the mononuclear molybdenum-containing enzymes hampered the detailed understanding of the mechanisms operating in these enzymes.
Investigation of the mechanism of molybdenum containing enzymes was considerably enhanced by the crystallographic determination of high-resolution 3D structure of the Dg aldehyde oxido-reductase (in 1995). ${ }^{80}$ The enzyme, belonging to the xanthine oxidase family, was a potential model for the mechanistic studies on this group of enzymes. Almost simultaneously, after the determination of the first 3-D structure of Dg aldehyde oxido-reductase, followed in 1996, the structural determination of Rhodobacter sphaeroides DMSO reductase, that allowed a direct comparison between molybdo- and tungsto-enzymes and showed how these apparently disparate enzymes are surprisingly related.

Molybdenum (together with Tungsten) is the heaviest element (metal) used by biology and plays relevant physiological roles in humans, with only four molybdoenzyme types: Xanthine oxidase, Aldehyde oxidase, Sulfite oxidase and Mitochondrial Amidoximereducing component. One of the molybdenum-dependent metabolic processes is purine catabolism. Xanthine oxidase is responsible for catalyzing the sequential hydroxylation of hypoxanthine, in general, producing urate, which, in humans, is the terminal product of purine catabolism. A high concentration of urate in the blood is a risk factor for gout deposition of monosodium urate crystals in and around the joints and the development of many other diseases (i.e. inflammatory arthritis). Major risk factors for gout include hyperuricaemia, genetics, dietary factors, and others. It is reported prevalence of gout worldwide ranges from $0.1 \%$ to approximately $10 \%$, and the incidence from 0.3 to 6 cases per 1,000 person-years. ${ }^{91}$

Different strategies, including increasing excretion and/or decreasing the formation of urate by inhibiting xanthine oxidase have been applied. For this reason, human xanthine oxidase is one of the targets of therapies against hyperuricemia and gout. The full characterization of Dg Aldehyde oxido-reductase (biochemical and

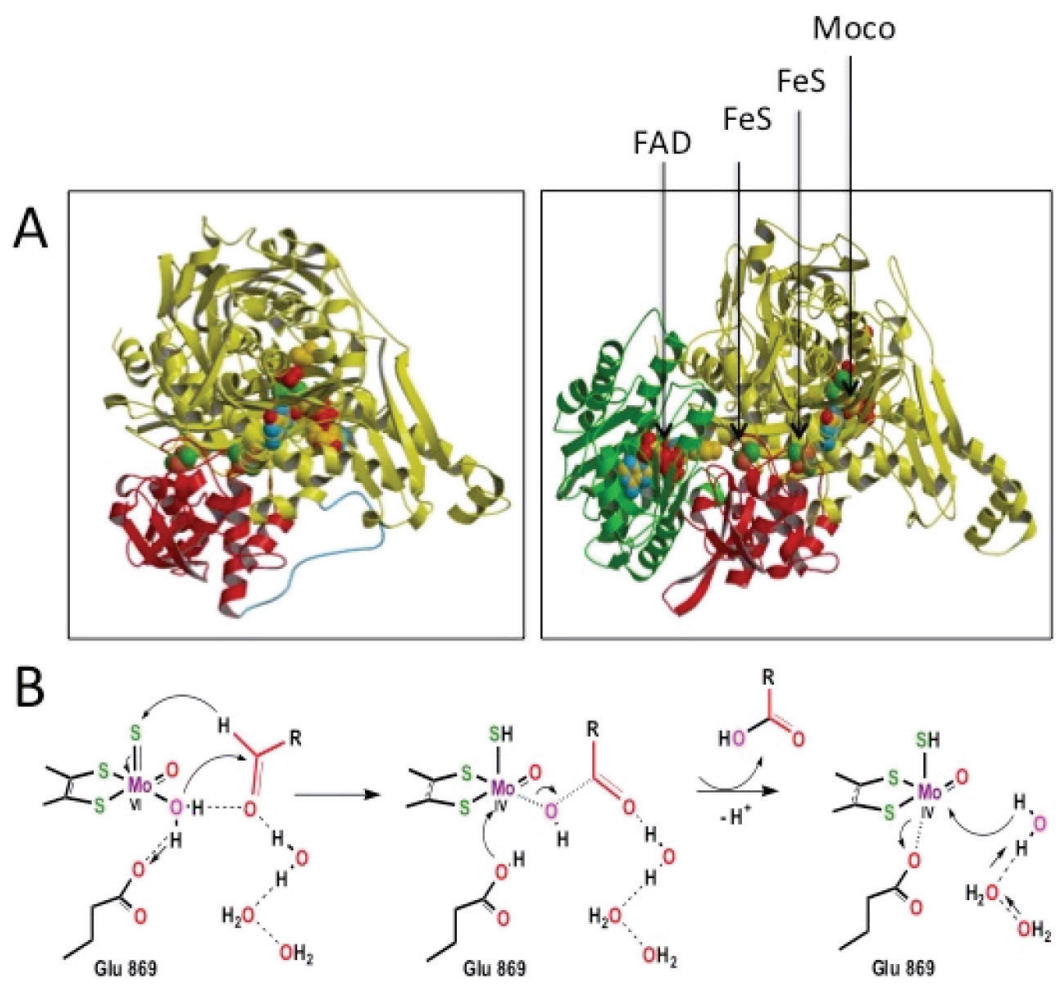

Figure 3. A) Xanthine oxidase (in right) contains four redox centers: Moco (the pterin cofactor is a molybdopterin cytosine dinucleotide), two (2Fe-2S) centers and a FAD moiety, while aldehyde oxido-reductase (in left) has strong analogies with Xanthine oxidase and the polypeptide chain folds into four domains: two bind the iron sulfur clusters and the others are associated with Moco. The additional domain (in green), that binds FAD in xanthine oxidase, is absent in Dg Aldehyde oxido-reductase (does not contain a flavin moiety), although it was recognized that a small flavodoxin participates in electron transfer instead. B) shows a proposed mechanism for the conversion of aldehydes in carboxylic acids based on Dg Aldehyde oxido-reductase structural studies (see text) ${ }^{76,94,95}$ 
first structural data) was a fundamental achievement during the period of lack of information on the related human enzymes (Xanthine oxidase and Aldehyde oxidase) enabling the proposal of mechanisms and inhibitory sites to be studied, for drug development.

A quite new aspect is the participation of molybdenum enzymes that are involved in a wide range of metabolic pathways may also utilize nitrite to the production of NO, a powerful signaling molecule, under anoxia. So, molybdenum enzymes have been described as "non dedicated" nitrite reductases, providing a mechanistic pathways for $\mathrm{O}$ atom abstraction, in alternative to $\mathrm{O}$ atom insertion, as depicted in the conversion of aldehydes to carboxylic acids, for example. ${ }^{92,93}$ These new discoveries might open pharmacological opportunities to modulate NO response under hypoxic conditions.

\section{BASIC RESEARCH, A BASIC HUMAN NEED BY REMI CHAUVIN}

The question of the usefulness or profitability of basic research (BR) is legitimate: BR has indeed a cost, which, beside private supports, must be mainly provided by public funding. According to the most recent OECD report for 44 countries, ${ }^{96}$ public BR expenditure corresponds to $\mathrm{ca} 0.4 \pm 0.3 \%$ of GDP, while the total public expenditure on Research and Development (R\&D) to $c a 0.6 \pm 0.3 \%$ of GDP. Within R\&D, the place of BR here deserves a special attention as opposed to applied research (AR), which is for its own part widely funded by the enterprise sector. The AR-BR dialectic is addressed below through (i) the societal context and (ii) selected illustrations of passages from BR discoveries to AR developments.

\section{The AR-BR dialectic: societal context}

What is basic research? Summarizing a current opinion, it might be quickly defined as an effort aiming at discoveries that could be appraised by very few people only, without prospect of short term application that could help in our daily life, for concrete comfort from health to gadget facilities - or abstract enjoyment - from art and knowledge to sport.

While concrete comfort should precisely result from AR taking over from BR, abstract enjoyment may refer to the enthusiasm of our ancestors, who started building cathedrals, knowing that they will never see their achievement. More than beauty, prospect of beauty inspired a collective force similar to that of the BR actors today. Just as art or sport through the construction cathedrals or stadiums, knowledge is a source of enjoyment through education. As knowledge continuously relies on BR outcomes, this view should make authorities more comfortable when funding BR for the sake of education, i.e. people's welfare.

\section{Selected stories: from BR discoveries to AR development}

The essence of BR is not to solve given problems and wait for others, but to explore new problems and inspire others, while remaining ready for serendipity and prospects of concrete applications. The process can be self-consistent, as tentatively illustrated below.

Plenty of examples can be found showing the possibility of unexpected practical aftermath of BR results, that could not have resulted from on-project programs of standard AR, even by serendipity: electricity was not invented by trying to improve the candle, a claim often attributed to Niels Bohr. ${ }^{97-99}$

In Niels Bohr's research field, by the way, i. e. quantum theory, a remarkable example in the sub-field of quantum chemistry is the basic Hohenberg-Kohn theorem (stating that the ground state energy of an electron system in a given external potential is uniquely determined through a functional of the electron density map). ${ }^{100}$ This opened the way to the Kohn-Sham equations of DFT computation, ${ }^{101}$ today widely used to calculate real molecular structures (instead of simplified models thereof) with high reliability and CPU time economy, both in BR labs and AR industrial centers.

In the parent context of quantum mechanics, the advent of quantum computers has just allowed a given computation to be performed in 200 seconds, instead of 10,000 years by the fastest classical computer. ${ }^{102}$ In 2019, this proof of concept of "Quantum Supremacy" opened "a new era in the computing industry", Prof. Robert Young said. ${ }^{103}$ This appears as a dialectic achievement, 90 years later of Paul Dirac's introductory statement of his seminal paper on Quantum mechanics of many-electron systems: ${ }^{104}$ "The underlying physical laws necessary for the mathematical theory of a large part of physics and the whole of chemistry are thus completely known, and the difficulty is only that the exact application of these laws leads to equations much too complicated to be soluble. It therefore becomes desirable that approximate practical methods of applying quantum mechanics should be developed, which can lead to an explanation of the main features of complex atomic systems without too much computation".

In the field of experimental chemistry, numerous discoveries could serve as pleadings for BR. Far from any medicinal application, early basic research concerns on chiral phosphorus compounds and asymmetric catalysis is eloquent: the findings of the efficiency of the DIOP ligand in enantioselective rhodium-catalyzed hydrogenation of dehydro-aminoacids, ${ }^{105}$ parallelized the way to the MONSANTO process for the industrial production of L-DOPA, the main prescribed drug against the Parkinson's disease. ${ }^{106}$ This illustrates of the AR-BR research complementarity for addressing challenges common to industrial and academic concerns.

In the backdrop of homogeneous catalysis, ligand design and coordination chemistry stand as more fundamental BR concerns, whose spinoffs are less patentable but can provide guidelines for applications, as for instance proposed by our "C-rich/P-poor polar ligands" typology. ${ }^{107-109}$ Other personal experiences are developed below.

At the frontier between conceptual and experimental chemistry, the basic issue of expanding the size of a molecule with a minimal change of its other characteristics led to our proposition, in 1995, of the notion of carbo-mer (see Scheme 1), along with first attempt at synthesis of carbo-benzene representatives. ${ }^{110}$ As ab initio ideas do not exist, it must be mentioned that the same kind of concern can be found implicitly addressed, albeit in a less general form, in previous reports on particular molecules. ${ }^{11,112}$ After 15 years of basic computational and experimental investigations of these "funny molecules"113 - Art for Art's sake, a few colleagues said -, properties bearing concrete prospects of applications started to appear (e.g. electrical, optical, liquid crystal properties), ${ }^{114}$ prevailing today with patent deposits (e.g. on sustainable hydrogen energy). ${ }^{115}$

Actually, the concept of carbo-mer is so basic that it is simple, and it could have been proposed decades before 1995. Surprisingly, however, it was simultaneously proposed in the specific case of the benzene molecule exactly at the same time (the same month of the same year in the same volume of the same journal) by Japanese and French authors, seemingly in an independent manner. ${ }^{110,116}$ Although it might just be incidental, one may also envisage that the idea was "floating in the air" in a subliminal manner through the common literature registry unifying International BR connections across the world. Several examples of such coincidences have been reported. For the sake of financial competition, such a connection is of course much weaker in industrial $R \& D$. The literature supports of the BR community and AR community have actually very different editorial spirits: while the former communicates through publications based 
Expanding the size of molecule with a minimal change of other basic characteristics (atomic connectivity, shape, absolute configuration, $\pi$-resonance...): by systematic $\mathrm{C}_{2}$ insertion from a representative Lewis structure $\Rightarrow>$ definition of carbo-mers

\begin{tabular}{|c|c|c|c|}
\hline - in single bonds: & $A-B$ & $\stackrel{\mathrm{C}_{2}}{\longrightarrow}$ & $A-C \equiv C-B$ \\
\hline - in double bonds: & $A=B$ & $\stackrel{\mathrm{C}_{2}}{\Longrightarrow}$ & $\mathrm{A}=\mathrm{C}=\mathrm{C}=\mathrm{B}$ \\
\hline - in triple bonds: & $A \equiv B$ & $\mathrm{C}_{2}$ & $A \equiv C-C \equiv B$ \\
\hline
\end{tabular}

Examples

- carbo-merization of methane derivatives:

- skeletal carbo-merization of ethene to butatriene:

- skeletal carbo-merization of acetylene to butadiyne:

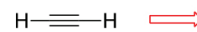

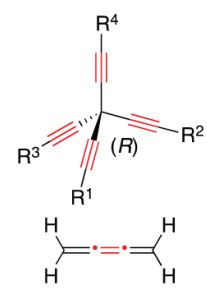
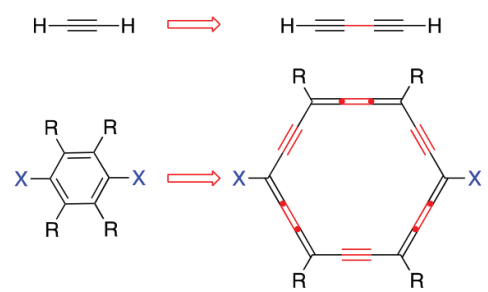

- skeletal carbo-merization of benznes to carbo-benzenes:

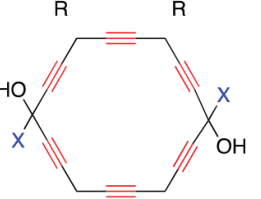

Scheme 1. Basic definition and examples of the notion of carbo-mer

on a peer-review evaluation process, the latter communicates through patents tending to present results in a legally minimal manner, sometime misleading on purpose.

As mentioned above, BR is essentially intended to be inspiring, and, for consistency, at first within the context of BR itself. This is what happened in 2003, as we wondered about the stability of carbo-benzene precursor in the flask. In the flask first, but why not in Nature? ${ }^{117,118}$ Inspection of the literature showed that a few molecules with similar structural features were indeed extracted from vegetal roots or animal organisms, such as carrots or marine sponges. ${ }^{19-125}$ As expected from their functionality foreshadowing reactivity, natural metabolites were described to exhibit biological properties, such as moderate anti-tumor activity. Nonetheless, the intriguing relative stability of such molecules in the biological medium of their hosts, prompted us and collaborators to play with their structure by superseding Nature in making artificial analogues. Entry on stage of synthetic chemistry led to bio-inspired targets, which, after isolation, turned out to exhibit up to 670 times the activity of their natural congeners against cancer cells. ${ }^{126}$ The molecules' targets in the cancer cells were then studied in a systematic manner by biologists, who evidenced an unprecedented mode of action. ${ }^{127}$

Today, a patent is underway while preclinical tests against particular virulent cancer cells are being undertaken. At the time of writing, the particular cancer must remain confidential until patent deposit, ${ }^{127}$ thus illustrating further the practical AR/BR research relationship. Fifteen years ago, the innocent wonder of basic chemists was far from imagining such an outcome of their basic questioning, all the more they were not identified by their peers in the category of medicinal chemists. Nevertheless, an intense cooperation at the basic research level with talented chemists in the field, and then with biologists, proved to be invaluable on the way to the application.

\section{MOLECULAR INSIGHT TO ORGANIC CATALYSIS BY PAUL BERNHARDT}

The total synthesis of biologically active natural products has led to worldwide deployment of otherwise inaccessible drugs with high activity against life threatening illnesses such as cancers, viruses and bacterial infections. Given the typical complexity of compounds with drug-like properties, bearing a variety of functional groups and alternative stereochemistry, selectivity in each synthetic step must be ensured for the target compound to be produced in a practical (and economically viable) yield. This requires catalysts that enable the selective reaction of functional groups to give desired compounds without indiscriminately affecting other sites on the molecule. In some ways, the catalyst may be seen as a magic 'black box' where reactants go in and the desired product comes out. If it works then everyone is happy and there may be little interest in understanding what happens 'inside the box'; in other words what is the mechanism?

In 1987 Ley and Griffith reported ${ }^{128}$ a new generally applicable way to selectively oxidise a primary alcohol to an aldehyde avoiding over-oxidation to the carboxylic acid or breaking $\mathrm{C}-\mathrm{C}$ bonds which can occur when alternative oxidants are used. The simple ruthenium catalyst (tetra- $n$-propylammonium perruthenate, $\mathrm{NPr}_{4}\left[\mathrm{RuO}_{4}\right]$ or TPAP, Scheme 2) has many desirable features including mild reaction conditions (high activity) and tolerance to other reactive groups (selectivity). In fact, the high demand for the catalyst TPAP led to it being made commercially available and it remains the reagent of choice for many reactions of this type. ${ }^{129}$ There are innumerable examples of the use of TPAP in organic synthesis, but one notable mention is its utilisation (three times) in the classic multi-step total synthesis of the drug $\operatorname{taxol}^{130}$ (Scheme 3).

In spite of its obvious effectiveness, little was known about the way TPAP actually worked (it remained a 'black box'). This 


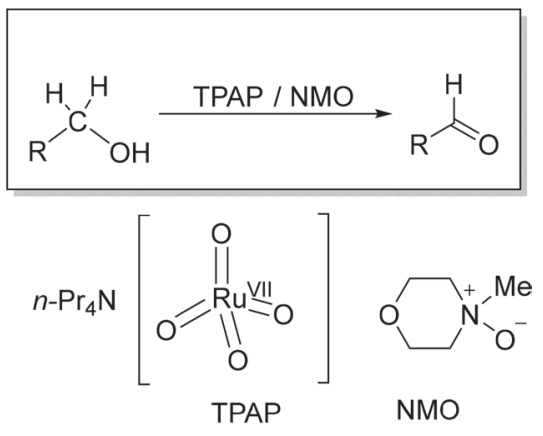

Scheme 2. The Ley-Griffith Oxidation Reaction

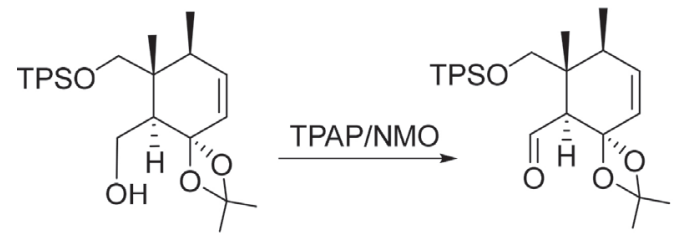

Scheme 3. One step in the total synthesis of taxol

included how it was regenerated during the reaction by its cooxidant $N$-methylmorpholine $N$-oxide (NMO) (Scheme 2). Our investigations were primarily aimed at gaining an understanding at the molecular level of how this reaction proceeded; curiosity driven research without an obvious end point or outcome. The driving force was to provide insight for the synthetic community on a popular but little understood reaction. Our initial studies showed that the alcohol oxidation reaction generated a highly reactive and unstable $\mathrm{Ru}^{\mathrm{V}}$ complex which was rapidly reoxidised by NMO to recover the $\mathrm{Ru}^{\mathrm{VII}}$ TPAP catalyst and sustain catalysis. ${ }^{131}$ However, further work revealed a more complicated picture.

In a catalytic (zero order) reaction a characteristic feature is that the rate of product formation is both rapid and constant over time and the reaction finishes when all reagents are used up. In the case of the TPAP-catalysed alcohol oxidation (Figure 4A), we were surprised to find ${ }^{132}$ that the reaction rate initially proceeded through a 'slow phase' but then unexpectedly accelerated to a 'rapid phase' before finishing when all alcohol had been oxidised to the product benzophenone.

Our study revealed much about the way this reaction works on the molecular level. However, the most surprising finding was that the reaction proceeds 'normally', without the slow phase (Figure 4B) if impure, commercially available TPAP (contaminated with $3 \%$ $\mathrm{RuO}_{2}$ ) is used. Indeed, most organic synthesis had been carried out with commercially available TPAP, so the (undesirable) slow phase had remained concealed over the 30-year use of the Ley-Griffith oxidation. An ironic discovery that goes against conventional wisdom that your reagents should be as pure as possible. If pure catalyst is used (Fig. 4, top - TPAP1, light yellow solution) then the abnormal behaviour in Figure 4A was seen. Commercially available TPAP catalyst (Fig. 4 top - TPAP2, dark brown solution) is only 97\% pure and the $3 \%$ impurity of insoluble $\mathrm{RuO}_{2}$ acts as a solid support on which the reaction proceeds more quickly.

This was basic research aimed at gaining a deeper insight into a popular reaction used by organic chemists worldwide. There was no intention to find a better catalyst than TPAP, it was merely the pursuit of knowledge utilising the collective skills of the collaborators from different areas (multi-disciplinary research). However, these outcomes will have implications for the way that this catalyst is used and stored into the future.

\section{METALS, DRUGS, CYANIDE AND TUBERCULOSIS - UNEXPECTED COMBINATION OF INSPIRATIONS BY EDUARDO SOUSA}

During the 1990s, I had the first opportunity as an undergraduate student to work in a research lab doing basic science in Chemistry. I was awarded a studentship from CNPq (a major Brazilian agency financing science), a very important financial support to engage young students in science. At that time I remember reading an exciting review about metals in medicine, ${ }^{133}$ which was an inspiration and motivated some of my early interests. However, much earlier, during the 1960s, the scientific community had already witnessed a major breakthrough in the use of metals in medicine. Considered mostly as toxic products, metal derivatives were not much seen as potential
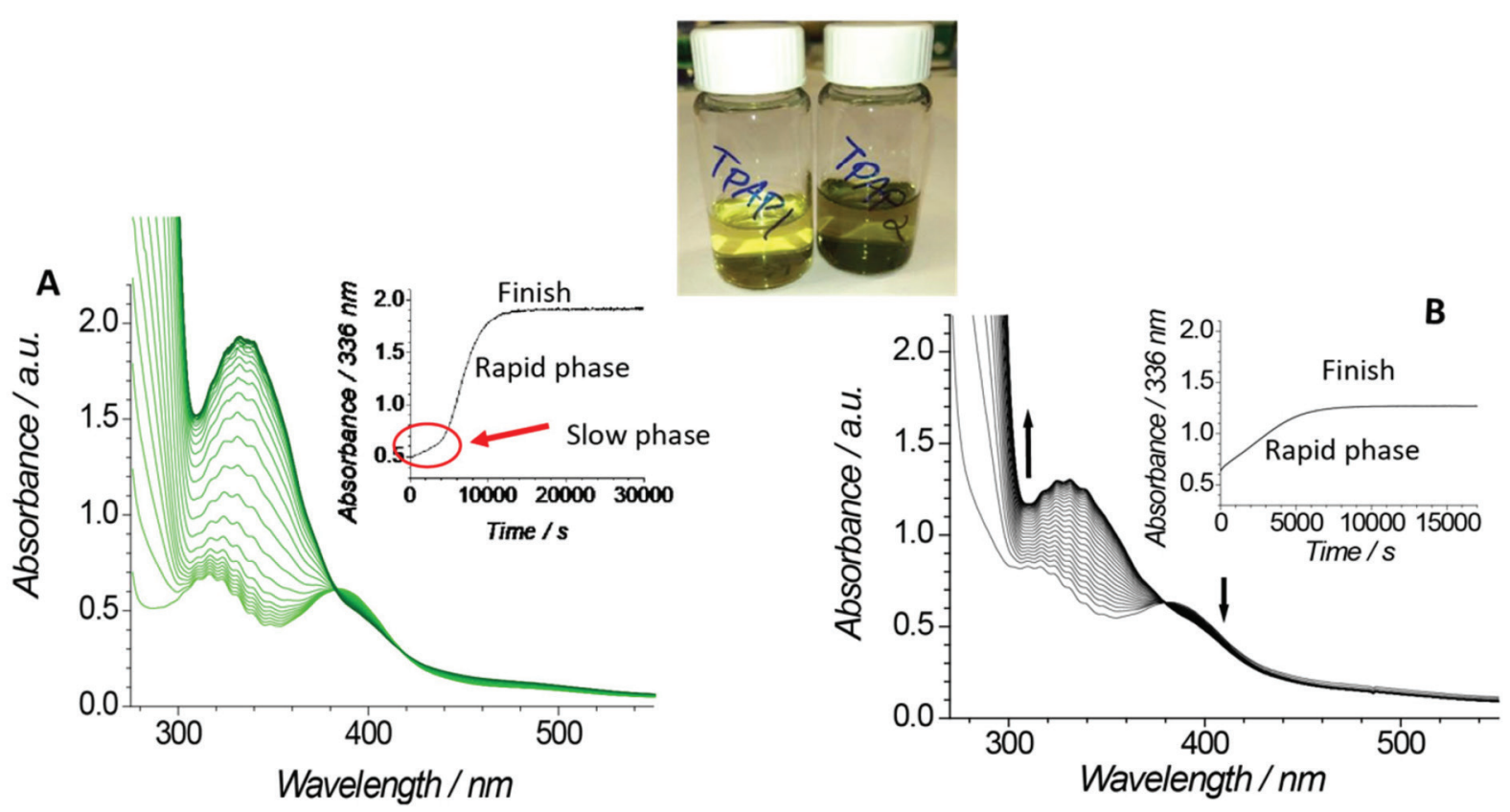

Figure 4. (A) TPAP/NMO oxidation of $\mathrm{Ph}_{2} \mathrm{CHOH}$ to $\mathrm{Ph}{ }_{2} \mathrm{CO}$ with pure TPAP (TPAP1, light yellow) showing initial slow phase; (B) the same reaction with commercially available (97\% pure) TPAP (TPAP2, dark brown) contaminated with $\mathrm{Ru}_{2}$. Reproduced from Ref. 128 with permission from the Royal Society of Chemistry 
medicines at all. Then, Dr Barnett Rosenberg at the Michigan State University (USA) changed everything. ${ }^{134} \mathrm{He}$ was studying how electric fields might affect cell division, and for that investigation he built an equipment to apply electric current. His hypothesis was that electric fields could locally perturb spindle formation during cell division. The first organism used in that study was a bacterium (Escherichia coli found in our intestine). It might be educational to ask if anyone would consider that work to be of any relevance to everyday life and worthy investigation. Why support a study on a "harmless" gut bacterium placed in an electric field at all? This is a typical case of basic research investigation, where "not much" was indeed expected, no product foreseen or major advance in knowledge follow, but such curiosity motivates scientists to search for new discoveries.

Remarkably, that study led to the development of one of the most important anticancer drugs ever produced, cisplatin $\left(\left[\mathrm{Pt}\left(\mathrm{NH}_{3}\right)_{2} \mathrm{Cl}_{2}\right]\right)$ (also briefly mentioned in the stories told by Peter Sadler, section 2). Indeed, at the beginning Rosenberg did not know anything about this platinum compound, or even from where it would come. ${ }^{135}$ During his studies applying electric fields to the bacteria, he noticed an abnormal elongation of the cells ( $\mathrm{ca}$. 300-fold longer than normal- filamentous growth) due to the lack of cell division. ${ }^{135}$ His thinking was that something was disrupting bacterial cell division and it might be useful to stop cancer propagation, where cells divide very fast. A hint from a chemist colleague about Pt reactivity made Rosenberg realize that the applied electric current was indeed oxidizing his electrode made of platinum metal (considered a quite inert material!). ${ }^{136}$ During application of an electric potential, in the presence of the cell medium, containing oxygen and $\mathrm{NH}_{4} \mathrm{Cl}$, minor amounts of a platinum compound were produced and eventually caused the observed growth effects on the bacteria. So, a search for platinum compounds which might be responsible for that took place. Later on, they tested a few platinum compounds as candidates for promoting that phenomenon, and identified cisplatin $\left(\left[\mathrm{Pt}\left(\mathrm{NH}_{3}\right) \mathrm{Cl}_{2}\right]\right)$ as a compound that can not only cause filamentous growth of bacteria but also kill cancer cell at very low doses. Interestingly, cisplatin had been prepared over a century before that (1844 by Michele Peyrone), ${ }^{137}$ but nobody knew it could be useful. Rosenberg decided to investigate its effect against a series of cancer cells and found out remarkable activity. Despite initial reluctance, the National Cancer Institute (USA) tested his compound and suggested he should apply for a grant with them, which was approved. ${ }^{135}$ From there, outstanding results were achieved, ${ }^{138}$ proving cisplatin was indeed a remarkable anticancer drug, leading to its clinical use in 1978 (Platinol®, BristolMyers Squibb). This very successful compound made possible the application of platinum in medicine, exhibiting a wide range of use in cancers, including lung, ovarian, bladder, testicular, head and neck, esophageal, colon, gastric, breast, melanoma, and prostate cancer. Since the introduction of cisplatin, for example, testicular cancer patients now have a remarkable cure rate of over 95\%. ${ }^{139}$ Around the globe, six platinum-based compounds have been approved for clinical use. ${ }^{140}$ Currently, the global market sales are over 1 billion US dollars per year, and many other transition metal compounds hold promise for future development. ${ }^{141}$ The success of this serendipitous discovery will motivate future generations of chemists, and highlights the importance of fundamental basic scientific studies for producing life-changing applications for all society. Scientists cannot foresee such applications with any certainty. They study what motivates them, based on their curiosity. Importantly they must be well trained and funded in order to explore, to see and unfold such a breakthrough as Rosenberg and his team achieved.

In another short story of basic science, I would mention a work developed in our lab starting with a synthesis of a new metal compound containing an organic ligand called thionicotinamide (similar to vitamin $\mathrm{B}_{3}$ ). The goal was to investigate the changes promoted by that ligand upon binding to the iron complex, in comparison to other analogous organic ligands, previously studied (e.g. nicotinamide, isonicotinamide, etc). This new compound would help us to understand and compare the effects that "minor" structural changes could cause on the new metal compound. So, we wish to measure the influence of that organic ligand in the color of the compound (changes in the orbital energies), its redox potential and eventually investigate electron transfer reactions.

The model iron compound that we were going to use in those studies was the sodium amminepentacyanoferrate(II), a complex that contained one ammonia $\left(\mathrm{NH}_{3}\right)$ and five cyanides $\left(\mathrm{CN}^{-}\right)$bound to iron(II); luckily those cyanides are tightly bound to the iron ion. Then, we would make a reaction where ammonia is replaced by thionicotinamide. Indeed, starting a project using a complex of iron containing those species would sound strange to a naïve student, and certainly much more for lay people. Why someone would be interested to work with something containing five cyanides, a well-known poison, ${ }^{142}$ and also ammonia, an irritating strong smelling base? But again, that was basic science, many times its impact is not immediately evident as previously discussed. Indeed, since 1970s, nitroprusside has been used as a drug in cases of hypertension emergency ${ }^{143}$ (another detailed story told by Luiz Lopes here, see section 1), where it contains five cyanides and one NO molecules, all of them bound to iron(II) (Figure 5). Another analogue drug containing six cyanides bound to iron(II) is also in clinical used as an antidote for poisoning by radioactive cesium-237 and thallium (radiogardase, FDA approved in 2003). These cases are a hint to avoid believing you know before knowing for sure.

Nonetheless, our basic study was carried out and we were able to prepare and isolate two new compounds of cyanoferrate with thionicotinamide, supposedly bound to iron(II) and another to iron(III) (Figure 5). Unfortunately (or fortunately), the cyanoferrate(III) complex with thionicotinamide showed spectroscopic (UV-vis, FTIR, RMN, Mossbauer) and chromatographic evidences of another compound containing cyanoferrate(II) and 4-cyanopyridine, instead of thionicotinamide. That result indicated a redox process happened likely promoted by iron(III) oxidizing thionicotinamide, which was not expected at that point. ${ }^{144} \mathrm{~A}$ literature search showed thionicotinamide had some interesting analogues with anti-tuberculosis drugs, called ethionamide and isoniazid. This latter is indeed one of the most efficient first-line anti-tuberculosis drug in use, but it has faced major issue with the development of resistance. ${ }^{145}$ Those drugs are indeed pro-drugs, meaning they could not cure tuberculosis unless they are converted (activated) to active species. Interestingly, the process of activation of those pro-drugs is carried out through a redox reaction, but they need to be mediated by enzymes only found within $M$. tuberculosis. All this history came to us as an inspiration to use basic science to work forward.

Then, we thought that if we prepare a cyanoferrate(II) complex containing isoniazid (Figure 5), which is stable as such, we might be able to activate isoniazid more easily without using enzymes. If we could do that, we might kill even isoniazid-resistant bacteria. Why did we think that was possible ? Because we knew from previous basic studies that iron(II) oxidation in those complexes was easier and faster to accomplish. Then, a series of studies were done to show that fast oxidation of iron(II) could be achieved, which would accelerate isoniazid oxidation and formation of active species without using mycobacterial enzymes. ${ }^{144,146-148}$ At the same time, outstanding collaborators helped us to investigate the potential biological action of that compound, called IQG607, and also of other analogues, ${ }^{145}$, 149 against $M t b$, where great activity was found along with exciting pharmacological properties. ${ }^{148,150-156}$ Tuberculosis still kills over 
1 million of people per year around the globe and there is a huge necessity for new antibiotic agents to protect the human race from stronger and drug resistant pathogens. Our history stands on basic science and the interest to better understand nature, which has led us to propose new strategies to tackle tuberculosis. More recently, we found out that the biological mechanism of IQG607 may not be through the original idea of a redox-mediated activation. ${ }^{156,157}$ Not always Nature works as we desire. Nevertheless, this compound is well advanced in pre-clinical trials studies ${ }^{150,151,158,159}$ and bears a good chance to move forward. Indeed, IQG607 seems a better option than isoniazid particularly when used in combination with rifampicin and pyrazinamide, which might even shorthen the length of TB treatment. ${ }^{159}$ Besides that, all these studies provided a basis for our lab to mature and design a series of novel metal complexes with potential medical applications.

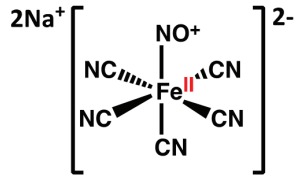

Nitroprusside

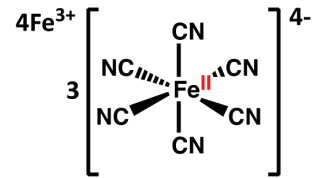

Radiogardase

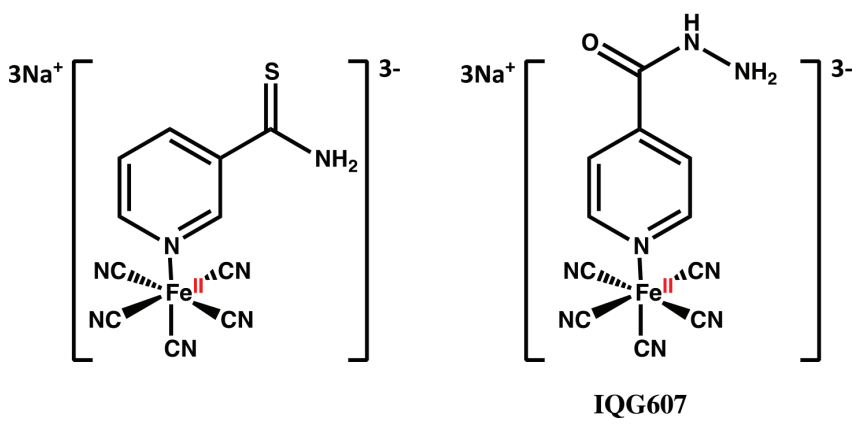

Figure 5. Some examples of cyanoferrate compounds including bound to thionicotinamide and isoniazid (IQG607)

\section{FINAL CONSIDERATIONS}

The above-reported stories provide a few examples within our own research fields at the intersection of Chemistry, Physics, Biology and Medicine, illustrating what basic science is and how it can improve our lives, or has the potential to. Basic science and applied science are intimately connected - without basic science there would not be applications, at least not game-changing applications. This situation should be reflected in funding - as a continuum. At first sight applied science might appear more attractive than basic research from the standpoint of short-term profitability, but it has been shown that basic research plays a major role in initiating and strengthening applied research.

Scientific research, which advances knowledge of this world we live in, is exciting, not only for young people, but throughout life. New research is vital - all existing theories and hypotheses need to be tested and reinvestigated- never believe what anyone tells you 'Nullius in verba'.

Academic freedom to pursue fundamental research within a University environment without an immediate application should be always nourished. Ultimately, the scientific community will evaluate the quality/originality of the research work through peer review and decide whether the work is important enough to warrant publication. Then, only History will define the true impact and value of the reported results.
Proper funding for scientific research is an investment not only in the lives of young people and the more senior scientists who train them, but also in the future health and well-being of all society. Curiosity-driven basic research is essentially creative, opening the way to further developments. It challenges highly motivated brilliant minds, without which, neither the progress nor the innovation could be possible. This key issue should not be forgotten by governments and also by lay people. Definitely, if a Country wants to be a leading edge in innovation and development in the future, there is no alternative but to invest wisely in basic research free from the requirements of short-term return on investment expectations.

As we mentioned here, basic research is the core of science and many exciting questions crossing even more a multidisciplinary frontier deserve funding and hold major potential outcomes. Despite many advances in our understanding (and use) of metals in biology, for example, we still face an extensive number of unknown answers, requiring to be addressed within an interdisciplinary network. For instance, the use of CRISPR (gene editing technology) can open even more opportunities to precisely modify genes in more complex organisms allowing us to better investigate the role of metal sites, metal transporters, metal chaperones, eventually allowing a more rational creation of artificial systems to deal with our current problems (e.g. oil degradation, new fuel/biomass production). The use of (bio) analytical tools (non-invasive in whole animals as well) may help us to answer complex questions relating to the fate and function of native and non-native metal complexes, for example, through a (epi)genomic, transcriptomic, (metallo)proteomic and metabolomic combined approach. Nanotechnology and advanced analytical tools amongst other topics can make important contributions in this field, calling for broad scientific networks. What and how non-metal-based drugs disturb metallomics is poorly known, but still need to be explored. Once we advance our fundamental understanding on how metals are handled in biology, and even which ones are truly needed (still a current question for some elements), then we can more rationally use them in medical applications and to improve our well-being, opening, then, new routes for innovation and discovery. It is remarkable how much we are now learning about the key role of metals in biology, but at the same time many things are still unknown. The key to understanding neurological disorders such as senile dementia, Parkinson's and Alzheimer's diseases may well lie in understanding the fundamental neurochemistry of metals such as iron, zinc, copper and manganese in the brain. These and many other basic questions being exciting, we should not restrain support and we must provide freedom for basic exploration studies, since they may unfold breakthroughs. In face of the outbreak of SARS$\mathrm{CoV}-2$, the role of science has become even more evident, and its absolute necessity is clear. Let us celebrate science and new knowledge, and cheer for much more to come.

\section{ACKNOWLEDGMENTS}

LGFL thanks for financial support provided by $\mathrm{CNPq}$ (303355/2018-2), CAPES-Cofecub (88887.130198/2017-01) and UFC. PJS thanks all the bodies which have supported our research, including recently the ERC (grant no. 247450), EPSRC (grant no. EP/F034210/1 and EP/P030572/1) Wellcome Trust (grant no. 107691/Z/15/Z), Royal Society, CRUK, and industry (Bruker, AngloAmerican). PJS also thanks his UK and international collaborators in Brazil and several other countries who have inspired and contributed greatly to his new discoveries. VBG dedicates this text to her first scientific advisors when she was still an undergraduate student: Anibal de Lima Pereira ${ }^{\dagger}$ and Eliezer Jesus Barreiro who taught her to love research. JJGM thanks the support of this work provided by the Associate Laboratory for Green 
Chemistry - LAQV, which is financed by national funds from FCT/ MCTES (UIDB/50006/2020. RC is indebted to his current and past confidence collaborators, students, post-docs, and former mentors or advisors. EHSS thanks all students involved in this collaborative research and CNPq (308383/2018-4, Universal 403866/2016-2, PDE 204177/2018-9, INCT/Tuberculosis (Decit/SCTIE/MS-MCT-CNPq FNDTC-CAPES-FAPERGS, 421703/2017-2), CAPES and FUNCAP for financial support, and UFC for infrastructure. EHSS would like to dedicate this article also to the memory of his $\mathrm{PhD}$ advisor, Dr Ícaro de Sousa Moreira $\left(2008^{\dagger}\right)$, a great professor, enthusiastic and inspiring researcher, and outstanding University administrator.

\section{REFERENCES}

1. https://www.globalresearchcouncil.org/meetings/annual-meetings/2019meeting/, accessed on June 2020.

2. https://www.chemistryworld.com/news/science-now-being-underminedby-us-government-on-an-almost-weekly-basis/4010502.article\#/, accessed on June 2020.

3. Tolley, K.; Hist. Educ. Quart. 2019, 59, 161.

4. Petersen, A. M.; Vincent, E. M.; Westerling, A. L.; Nat. Commun. 2019, 10,3502 .

5. Starr, D.; Science 2020, 367, 16

6. Nature's Editorial; Nature 2019, 572, 153.

7. Hotez, P.; J. Clin. Invest. 2019, 129, 2169.

8. Pollard, T. D.; Cell 2012, 151, 239.

9. Lee, C. M.; Trends Immunol. 2016, 37, 265.

10. Escobar, H.; Science 2019, 365, 419.

11. W.H.O.; Lancet Glob. Health 2019, 7, e1332.

12. Ignarro, L. J.; Cirino, G.; Casini, A.; Napoli, C.; J. Cardiovasc. Pharm. 1999, 34,879 .

13. Hottinger, D. G.; Beebe, D. S.; Kozhimannil, T.; Prielipp, R. C.; Belani, K. G.; J. Anaesthesiol. Clin. Pharmacol. 2014, 30, 462.

14. Ivankovich, A. D.; Miletich, D. J.; Tinker, J. H.; Int. Anesthesiol. Clin. 1978, 16,1 .

15. Playfair, L.; Philos. Trans. R. Soc. London 1851, 139, 846.

16. Johnson, C. C.; Proc. Soc. Exp. Biol. Med. 1928, 26, 102.

17. Page, I. H.; Corcoran, A. C.; Dustan, H. P.; Koppanyi, T.; Circulation 1955, 11, 188.

18. Vesey, C. J.; Cole, P. V.; Simpson, P. J.; Brit. J. Anaesth. 1976, 48 651 .

19. Arnold, W. P.; Longnecker, D. E.; Epstein, R. M.; Anesthesiology 1984, $61,254$.

20. Gobbel, G. T.; Chan, T. Y. Y.; Chan, P. H.; J. Pharmacol. Exp. Ther. 1997, 282, 1600.

21. Niknahad, H.; OBrien, P. J.; Biochem. Pharmacol. 1996, 51, 1031.

22. Kanthasamy, A. G.; Ardelt, B.; Malave, A.; Mills, E. M.; Powley, T. L.; Borowitz, J. L.; Isom, G. E.; Toxicol. Lett. 1997, 93, 47.

23. Silva Filho, P. M.; Paz, I. A.; Nascimento, N. R. F.; Santos, C. F.; Araujo, V. R.; Aquino, C. P.; Ribeiro, T. S.; Vasconcelos, I. F.; Lopes, L. G. F.; Sousa, E. H. S.; Longhinotti, E.; Mol. Pharm. 2019, 16, 2912.

24. Leitao Junior, A. S.; Campos, R. M.; Cerqueira, J. B.; Fonteles, M. C.; Santos, C. F.; de Nucci, G.; Sousa, E. H. S.; Lopes, L. G.; GonzagaSilva, L. F.; Nascimento, N. R.; Int. J. Impot. Res. 2016, 28, 20.

25. Campelo, M. W.; Oria, R. B.; Lopes, L. G.; Brito, G. A.; Santos, A. A.; Vasconcelos, R. C.; Silva, F. O.; Nobrega, B. N.; Bento-Silva, M. T.; Vasconcelos, P. R.; Neurochem. Res. 2012, 37, 749.

26. Silva, J. J.; Guedes, P. M.; Zottis, A.; Balliano, T. L.; Nascimento Silva, F. O.; Franca Lopes, L. G.; Ellena, J.; Oliva, G.; Andricopulo, A. D.; Franco, D. W.; Silva, J. S.; Br. J. Pharmacol. 2010, 160, 260.

27. Pavanelli, W. R.; da Silva, J. J.; Panis, C.; Cunha, T. M.; Costa, I. C.; de Menezes, M. C.; Oliveira, F. J.; Lopes, L. G.; Cecchini, R.; Cunha Fde, Q.; Watanabe, M. A.; Itano, E. N.; Mycopathology 2011, 172, 95.
28. Santana, A. P.; Tavares, B. M.; Lucetti, L. T.; Gouveia, F. S., Jr.; Ribeiro, R. A.; Soares, P. M.; Sousa, E. H. S.; Lopes, L. G.; Medeiros, J. V.; Souza, M. H.; Nitric Oxide 2015, 45, 35.

29. Orsini, T. M.; Kawakami, N. Y.; Panis, C.; Thomazelli, A. P. F. D.; Tomiotto-Pellissier, F.; Cataneo, A. H. D.; Kian, D.; Yamauchi, L. M.; Gouveia, F. S.; Lopes, L. G. D.; Cecchini, R.; Costa, I. N.; da Silva, J. J. N.; Conchon-Costa, I.; Pavanelli, W. R.; Mediat. Inflamm. 2016, $2631625,1$.

30. Nascimento, N. R. F.; Aguiar, F. L. N.; Santos, C. F.; Costa, A. M. L.; Hardoim, D. J.; Calabrese, K. D. S.; Almeida-Souza, F.; Sousa, E. H. S.; Lopes, L. G. F.; Teixeira, M. J.; Pereira, V. S.; Brilhante, R. S. N.; Rocha, M. F. G.; Acta Trop. 2019, 192, 61.

31. Sousa, E. H. S.; Ridnour, L. A.; Gouveia, F. S., Jr.; Silva da Silva, C. D.; Wink, D. A.; Lopes, L. G. F.; Sadler, P. J.; ACS Chem. Biol. 2016, 11, 2057.

32. Staurengo-Ferrari, L.; Mizokami, S. S.; Silva, J. J.; da Silva, F. O.; Sousa, E. H. S.; da Franca, L. G.; Matuoka, M. L.; Georgetti, S. R.; Baracat, M. M.; Casagrande, R.; Pavanelli, W. R.; Verri, W. A., Jr.; Pharmacol. Biochem. Behav. 2013, 105, 157.

33. Cerqueira, J. B.; Silva, L. F.; Lopes, L. G.; Moraes, M. E.; Nascimento, N. R.; Int. Braz. J. Urol. 2008, 34, 638.

34. Silva, C. D. S.; Paz, I. A.; Abreu, F. D.; de Sousa, A. P.; Verissimo, C. P.; Nascimento, N. R. F.; Paulo, T. F.; Zampieri, D.; Eberlin, M. N.; Gondim, A. C. S.; Andrade, L. C.; Carvalho, I. M. M.; Sousa, E. H. S.; Lopes, L. G. F.; J. Inorg. Biochem. 2018, 182, 83.

35. Staurengo-Ferrari, L.; Mizokami, S. S.; Fattori, V.; Silva, J. J.; Zanichelli, P. G.; Georgetti, S. R.; Baracat, M. M.; da Frana, L. G.; Pavanelli, W. R.; Casagrande, R.; Verri, W. A.; N-S Arch. Pharmacol. 2014, 387, 1053.

36. Rossaneis, A. C.; Longhi-Balbinot, D. T.; Bertozzi, M. M.; Fattori, V.; Segato-Vendrameto, C. Z.; Badaro-Garcia, S.; Zaninelli, T. H.; Staurengo-Ferrari, L.; Borghi, S. M.; Carvalho, T. T.; Bussmann, A. J. C.; Gouveia, F. S., Jr.; Lopes, L. G. F.; Casagrande, R.; Verri, W. A., Jr.; Front. Pharmacol. 2019, 10, 229.

37. Liu, H. A.; Balkus, K. J.; Chem. Mater. 2009, 21, 5032.

38. Ninan, N.; Muthiah, M.; Park, I. K.; Wong, T. W.; Thomas, S.; Grohens, Y.; Polym. Rev. 2015, 55, 453.

39. Lowe, A.; Bills, J.; Verma, R.; Lavery, L.; Davis, K.; Balkus, K. J., Jr.; Acta Biomater. 2015, 13, 121.

40. Carpenter, A. W.; Schoenfisch, M. H.; Chem. Soc. Rev. 2012, 41, 3742.

41. Sousa, E. H. S.; Tuckerman, J. R.; Gonzalez, G.; Gilles-Gonzalez, M. A.; Protein Sci. 2007, 16, 1708.

42. Sousa, E. H. S.; Gilles-Gonzalez, M. A.; Adv. Microb. Physiol. 2017, 71, 235 .

43. The Royal College of Radiologists, Guidance on gadolinium-based contrast agent administration to adult patients, Royal College of Radiologists, Ref No. BFCR(19)4, London, 2019.

44. Chellan, P.; Sadler, P. J.; Philos. Trans. R. Soc., A 2015, 373.

45. Imberti, C.; Sadler, P. J. In Advances in Inorganic Chemistry; Sadler, P. J., van Eldik, R., eds.; Elsevier: Amsterdam, 2020, ch. 1, p. 3.

46. Needham, R. J.; Sadler, P. J. In The Periodic Table II; Mingos, D., ed.; Springer: New York, 2019, vol. 182, p. 175.

47. do Nascimento, A. S.; Gondim, A. C.; Cajazeiras, J. B.; Correia, J. L.; Pires Ade, F.; do Nascimento, K. S.; da Silva, A. L.; Nagano, C. S.; Assreuy, A. M.; Cavada, B. S.; J. Mol. Recognit. 2012, 25, 657.

48. Gondim, A. C. S.; Romero-Canelon, I.; Sousa, E. H. S.; Blindauer, C. A.; Butler, J. S.; Romero, M. J.; Sanchez-Cano, C.; Sousa, B. L.; Chaves, R. P.; Nagano, C. S.; Cavada, B. S.; Sadler, P. J.; J. Inorg. Biochem. 2017, 175, 179.

49. Gondim, A. C. S.; Roberta da Silva, S.; Mathys, L.; Noppen, S.; Liekens, S.; Holanda Sampaio, A.; Nagano, C. S.; Renata Costa Rocha, C.; Nascimento, K. S.; Cavada, B. S.; Sadler, P. J.; Balzarini, J.; MedChem Comm 2019, 10, 390. 
50. Semenza, G. L.; Nejfelt, M. K.; Chi, S. M.; Antonarakis, S. E.; Proc. Natl. Acad. Sci. U. S. A. 1991, 88, 5680.

51. Semenza, G. L.; Oncogene 2010, 29, 625.

52. Hearn, J. M.; Romero-Canelon, I.; Munro, A. F.; Fu, Y.; Pizarro, A. M.; Garnett, M. J.; McDermott, U.; Carragher, N. O.; Sadler, P. J.; Proc. Natl. Acad. Sci. U. S. A. 2015, 112, E3800.

53. Christie, D. A.; Tansey, E. M., (eds). The Discovery, Use and Impact of Platinum Salts as Chemotherapy Agents for Cancer. Wellcome Witnesses to Twentieth Century Medicine, vol. 30. London: Wellcome Trust Centre for the History of Medicine at UCL. 2007. http://www. histmodbiomed.org/sites/default/files/44855.pdf

54. Imberti, C.; Zhang, P. Y.; Huang, H. Y.; Sadler, P. J.; Angew. Chem., Int. Ed. 2019, 59, 61.

55. Oliveira, C. G.; Romero-Canelón, I.; Silva, M. M.; Coverdale, J. P. C.; Maia, P. I. S.; Batista, A. A.; Castelli, S.; Desideri, A.; Sadler, P. J.; Deflon, V. M.; Dalton Trans. 2019, 48, 16509.

56. Bernardes-Genisson, V. In Traité de Chimie Thérapeutique Médicaments antitumoraux et perspectives dans le traitement des cancers, TEC\&DOC and Editions Médicales Internationales: Paris, 2003, ch. 31, p. 651.

57. Nicolau, K. C.; Montagnon, T. In Molecules that changed the world, Wiley-VCH: Weinheim, 2008, ch. 25, p. 207.

58. Nicolaou, K. C.; Yang, Z.; Liu, J. J.; Ueno, H.; Nantermet, P. G.; Guy, R. K.; Claiborne, C. F.; Renaud, J.; Couladouros, E. A.; Paulvannan, K.; Sorensen, E. J.; Nature 1994, 367, 630.

59. Holton, R. A.; Somoza, C.; Kim, H. B.; Liang, F.; Biediger, R. J.; Boatman, P. D.; Shindo, M.; Smith, C. C.; Kim, S. C.; Nadizadeh, H.; Suzuki, Y.; Tao, C. L.; Vu, P.; Tang, S. H.; Zhang, P. S.; Murthi, K. K.; Gentile, L. N.; Liu, J. H.; J. Am. Chem. Soc. 1994, 116, 1597.

60. Holton, R. A.; Kim, H. B.; Somoza, C.; Liang, F.; Biediger, R. J.; Boatman, P. D.; Shindo, M.; Smith, C. C.; Kim, S. C.; Nadizadeh, H.; Suzuki, Y.; Tao, C. L.; Vu, P.; Tang, S. H.; Zhang, P. S.; Murthi, K. K.; Gentile, L. N.; Liu, J. H.; J. Am. Chem. Soc. 1994, 116, 1599.

61. Wani, M. C.; Taylor, H. L.; Wall, M. E.; Coggon, P.; McPhail, A. T.; J. Am. Chem. Soc. 1971, 93, 2325.

62. Corey, E. J.; Li, J. J.; Total Synthesis of Natural Product, Springer \& Verlag: Berlin, 2012.

63. Herranz, E.; Biller, S. A.; Sharpless, K. B.; J. Am. Chem. Soc. 1978, 100, 3596.

64. Wuts, P. G. M.; Greene, T. W.: Protective groups in organic synthesis, John Wiley \& Sons: New Jersey, 2007.

65. Guenard, D.; Guerittevoegelein, F.; Potier, P.; Acc. Chem. Res. 1993, 26, 160.

66. Sneader, W.; Drug discovery: history, John Wiley \& Sons, Chichester, 2005.

67. Chollet, A.; Mourey, L.; Lherbet, C.; Delbot, A.; Julien, S.; Baltas, M.; Bernadou, J.; Pratviel, G.; Maveyraud, L.; Bernardes-Genisson, V.; J. Struct. Biol. 2015, 190, 328.

68. Bernardes-Genisson, V.; Deraeve, C.; Chollet, A.; Bernadou, J.; Pratviel, G.; Curr. Med. Chem. 2013, 20, 4370.

69. Laborde, J.; Deraeve, C.; Bernardes-Genisson, V.; ChemMedChem 2017, $12,1657$.

70. Laborde, J.; Deraeve, C.; Duhayon, C.; Pratviel, G.; BernardesGenisson, V.; Org. Biomol. Chem. 2016, 14, 8848.

71. Stigliani, J. L.; Bernardes-Genisson, V.; Ann. Pharm. Fr. 2019, 77, 126.

72. Moura, J. J. G.; Xavier, A. V.; Bruschi, M.; Legall, J.; Hall, D. O.; Cammack, R.; Biochem. Bioph. Res. Co. 1976, 72, 782.

73. Bray, R. C.; Turner, N. A.; Legall, J.; Barata, B. A. S.; Moura, J. J. G.; Biochem J. 1991, 280, 817 .

74. Moura, J. J. G.; Barata, B. A. S.; Method Enzymol. 1994, 243, 24.

75. Moura, J. J. G.; Bernhardt, P. V.; Maia, L. B.; Gonzalez, P. J.; J. Biol. Inorg. Chem. 2015, 20, 181

76. Brondino, C. D.; Romao, M. J.; Moura, I.; Moura, J. J. G.; Curr. Opin.
Chem. Biol. 2006, 10, 109 .

77. Maia, L. B.; Moura, I.; Moura, J. J. G. In Molybdenum and Tungsten Enzyme; Hille, R., Schulzke, C., Kirk, M. L., eds.; RSC Books: London, 2017, vol. 1, ch. 1, p. 1

78. Turner, N.; Barata, B.; Bray, R. C.; Deistung, J.; Legall, J.; Moura, J. J. G.; Biochem J. 1987, 243, 755.

79. Correia, H. D.; Marangon, J.; Brondino, C. D.; Moura, J. J. G.; Romao, M. J.; Gonzalez, P. J.; Santos-Silva, T.; J. Biol. Inorg. Chem. 2015, 20, 219.

80. Romao, M. J.; Archer, M.; Moura, I.; Moura, J. J. G.; Legall, J.; Engh, R.; Schneider, M.; Hof, P.; Huber, R.; Science 1995, 270, 1170.

81. Rebelo, J. M.; Dias, J. M.; Huber, R.; Moura, J. J. G.; Romao, M. J.; J. Biol. Inorg. Chem. 2001, 6, 791.

82. Enroth, C.; Eger, B. T.; Okamoto, K.; Nishino, T.; Nishino, T.; Pai, E. F.; Proc. Natl. Acad. Sci. U. S. A. 2000, 97, 10723.

83. Rebelo, J.; Macieira, S.; Dias, J. M.; Huber, R.; Ascenso, C. S.; Rusnak, F.; Moura, J. J. G.; Moura, I.; Romao, M. J.; J. Mol. Biol. 2000, 297, 135.

84. Duarte, R. O.; Archer, M.; Dias, J. M.; Bursakov, S.; Huber, R.; Moura, I.; Romao, M. J.; Moura, J. J. G.; Biochem. Bioph. Res. Co. 2000, 268, 745 .

85. Mota, C.; Coelho, C.; Leimkuhler, S.; Garattini, E.; Terao, M.; SantosSilva, T.; Romao, M. J.; Coord. Chem. Rev. 2018, 368, 35

86. Kumar, R.; Joshi, G.; Kler, H.; Kalra, S.; Kaur, M.; Arya, R.; Med. Res. Rev. 2018, 38, 1073.

87. Sanoh, S.; Tayama, Y.; Sugihara, K.; Kitamura, S.; Ohta, S.; Drug Metab. Pharmacokinet. 2015, 30, 52.

88. Garattini, E.; Terao, M.; Drug Metab. Rev. 2011, 43, 374.

89. Akabane, T.; Tanaka, K.; Irie, M.; Terashita, S.; Teramura, T.; Xenobiotica 2011, 41, 372

90. Pryde, D. C.; Dalvie, D.; Hu, Q.; Jones, P.; Obach, R. S.; Tran, T. D.; J. Med. Chem. 2010, 53, 8441.

91. Kuo, C. F.; Grainge, M. J.; Zhang, W.; Doherty, M.; Nat. Rev. Rheumatol. 2015, 11, 649.

92. Maia, L. B.; Moura, J. J. G.; Redox Biol. 2018, 19, 274.

93. Maia, L. B.; Moura, J. J.; J. Biol. Inorg. Chem. 2015, 20, 403.

94. Romao, M. J.; Cunha, C. A.; Brondino, C. D.; Moura, J. J. G.; Met. Ions Biol. Syst. 2002, 39, 539 .

95. Huber, R.; Hof, P.; Duarte, R. O.; Moura, J. J. G.; Moura, I.; Liu, M. Y.; LeGall, J.; Hille, R.; Archer, M.; Romao, M. J.; Proc. Natl. Acad. Sci. U. S. A. 1996, 93, 8846.

96. OECD; Main Science and Technology Indicators, OECD Publishing, Paris, 2019, vol. 2019, p. 15, Table 6.

97. Grégoire, J.; Estudos de Psicologia 2018, 35, 229.

98. Salomé, J., Une vie à se dire - Ce n'est pas en perfectionnant la chandelle qu'on a inventé l'électricité, Les Éditions de L'Homme, Montréal - Paris, 2003.

99. Note: especially in the French-speaking community under the translation "ce n'est pas en perfectionnant la chandelle qu'on a inventé l'électricité", albeit without explicit reference, see ref. 97.

100. Hohenberg, P.; Kohn, W.; Phys. Rev. B 1964, 136, B864

101. Kohn, W.; Sham, L. J.; Phys. Rev. 1965, 140, 1133.

102. https://www.popularmechanics.com/technology/a29190975/googlequantum-supremacy/, accessed June 2020.

103. https://www.lancaster.ac.uk/quantum-technology/, accessed on June 2020.

104. Dirac, P. A. M.; Proc. R. Soc. London, Ser. A 1929, 123, 714.

105. Kagan, H. B.; Dang, T. P.; J. Am. Chem. Soc. 1972, 94, 6429.

106. Knowles, W. S.; Acc. Chem. Res. 1983, 16, 106

107. Chauvin, R.; Eur. J. Inorg. Chem. 2000, 577.

108. Lepetit, C.; Maraval, V.; Canac, Y.; Chauvin, R.; Coord. Chem. Rev. 2016, 308, 59.

109. Dubrulle, L.; Poidevin, C.; Maaliki, C.; Canac, Y.; Lepetit, C.; Duhayon, C.; Chauvin, R.; Eur. J. Inorg. Chem. 2016, 3, 313. 
110. Chauvin, R.; Tetrahedron Lett. 1995, 36, 397.

111. Sworski, T. J.; J. Chem. Phys. 1948, 16, 550.

112. Scott, L. T.; Decicco, G. J.; Hyun, J. L.; Reinhardt, G.; J. Am. Chem. Soc. 1983, 105, 7760.

113. Chauvin, R.; Tetrahedron Lett. 1995, 36, 401.

114. Cocq, K.; Barthes, C.; Rives, A.; Maraval, V.; Chauvin, R.; Synlett 2019, 30,30 .

115. Cure, J.; Cocq, K.; Mlayah, A.; Hungria, T.; Alphonse, P.; Chabal, Y. J.; Maraval, V.; Chauvin, R.; Estève, A.; Rossi, C.; International Journal of Hydrogen Energy 2019, 44, 26347.

116. Kuwatani, Y.; Watanabe, N.; Ueda, I.; Tetrahedron Lett. 1995, 36, 119.

117. Peyrou, V.; Chauvin, R.; unpublished results, University of Toulouse 2004.

118. Ayad, T.; Chauvin, R.; unpublished results, University of Toulouse 2005

119. Gunasekera, S. P.; Faircloth, G. T.; J. Org. Chem. 1990, 55, 6223.

120. Seo, Y.; Cho, K. W.; Rho, J. R.; Shin, J.; Sim, C. J.; Tetrahedron 1998 $54,447$.

121. Lim, Y. J.; Kim, J. S.; Im, K. S.; Jung, J. H.; Lee, C. O.; Hong, J.; Kim, D.; J. Nat. Prod. 1999, 62, 1215.

122. Bohlmann, F.; Arndt, C.; Bornowski, H.; Kleine, K. M.; Chem. Ber./ Recl. 1961, 94, 958.

123. Trager, W. F.; Lee, C. M.; Beckett, A. H.; Tetrahedron 1967, 23, 365

124. Bentley, R. K.; Thaller, V.; Chem. Commun. 1967, 9, 439.

125. Hansen, S. L.; Purup, S.; Christensen, L. P.; J. Sci. Food Agr. 2003, 83, 1010.

126. Listunov, D.; Joly, E.; Rulliere, P.; Gaspard, H.; Bernardes-Genisson, V.; Genisson, Y.; Maraval, V.; Chauvin, R.; Synthesis 2018, 50, 3114

127. Britton, S.; Joly, E.; Calsou, P.; Listunov, D.; Gaspard, H.; Rullière, P.; Genisson, Y.; Barthes, C.; Maraval, V.; Chauvin, R.; unpublished results and patent, 2020.

128. Griffith, W. P.; Ley, S. V.; Whitcombe, G. P.; White, A. D.; Chem. Comm. $\mathbf{1 9 8 7}, 24,1625$.

129. Ley, S. V.; Norman, J.; Griffith, W. P.; Marsden, S. P.; Synthesis 1994, $1994,639$.

130. Nicolaou, K. C.; Yang, Z.; Liu, J. J.; Ueno, H.; Nantermet, P. G.; Guy, R. K.; Claiborne, C. F.; Renaud, J.; Couladouros, E. A.; Paulvannan, K.; Sorensen, E. J.; Nature 1994, 367, 630.

131. Zerk, T. J.; Moore, P. W.; Williams, C. M.; Bernhardt, P. V.; Chem. Commun. 2016, 52, 10301.

132. Zerk, T. J.; Moore, P. W.; Harbort, J. S.; Chow, S.; Byrne, L.; Koutsantonis, G. A.; Harmer, J. R.; Martínez, M.; Williams, C. M.; Bernhardt, P. V.; Chem. Sci. 2017, 8, 8435.

133. Guo, Z.; Sadler, P. J.; Angew. Chem., Int. Ed. Engl. 1999, 38, 1512.

134. Lippert, B.; Cisplatin: Chemistry and Biochemistry of a Leading Anticancer Drug, Verlag Helvetica Chimica Acta: Zurich, 1999.

135. Rosenberg, B.; Int. Sci. Rev. 1978, 3, 134.

136. Hoeschele, J. D.; Dalton Trans. 2009, 48, 10648.

137. Peyrone, M.; Ann. Chem. Pharm. 1844, 51, 1 .

138. Rosenberg, B.; VanCamp, L.; Trosko, J. E.; Mansour, V. H.; Nature 1969, 222, 385.

139. Howlader, N.; Noone, A. M.; Krapcho, M.; Neyman, N.; Aminou, R.; Waldron, W.; Altekruse, S. F.; Kosary, C. L.; Ruhl, J.; Tatalovich, Z.; Cho, H.; Mariotto, A.; Eisner, M. P.; Lewis, D. R.; Chen, H. S.; Feuer, E. J.; Cronin, K. A., SEER Cancer Statistics Review, 1975-2009, National Cancer Institute: Bethesda, MD, 2012.

140. Venkatesh, V.; Sadler, P. J.; Met. Ions Life Sci. 2018, 18.
141. Barry, N. P.; Sadler, P. J.; Chem. Commun. 2013, 49, 5106.

142. Note: Sodium cyanide ( $\mathrm{NaCN}$ ) was widely used as a poison to kill mice, and is very dangerous, $40 \mathrm{mg}$ can be lethal to a $70 \mathrm{~kg}$ man. Nazis also used cyanide, under the acid form $\mathrm{HCN}$, in their atrocities to exterminate millions of Jews in the gas chambers during the II World War.

143. Friederich, J. A.; Butterworth, J. F. t.; Anesth. Analg. 1995, 81, 152.

144. Sousa, E. H. S.; Pontes, D. L.; Diogenes, I. C.; Lopes, L. G.; Oliveira, J. S.; Basso, L. A.; Santos, D. S.; Moreira, I. S.; J. Inorg. Biochem. 2005, $99,368$.

145. Laborde, J.; Deraeve, C.; de Mesquita Vieira, F. G.; Sournia-Saquet, A.; Rechignat, L.; Villela, A. D.; Abbadi, B. L.; Macchi, F. S.; Pissinati, K.; Bizarro, C. V.; Machado, P.; Basso, L. A.; Pratviel, G.; de Franca Lopes, L. G.; Sousa, E. H. S.; Bernardes-Genisson, V.; J. Inorg. Biochem. 2017, 179,71

146. Sousa, E. H. S.; Basso, L. A.; Santos, D. S.; Diogenes, I. C. N.; Longhinotti, E.; Lopes, L. G. D.; Moreira, I. D.; J. Biol. Inorg. Chem. 2012, 17, 275

147. Sousa, E. H. S.; Vieira, F. G. D.; Butler, J. S.; Basso, L. A.; Santiago, D. S.; Diogenes, I. C. N.; Lopes, L. G. D.; Sadler, P. J.; J. Inorg. Biochem. 2014, 140, 236.

148. Oliveira, J. S.; Sousa, E. H. S.; Basso, L. A.; Palaci, M.; Dietze, R.; Santos, D. S.; Moreira, I. S.; Chem. Commun. 2004, 312.

149. Gazzi, T. P.; Rotta, M.; Villela, A. D.; Rodrigues, V.; Martinelli, L. K. B.; Sales, F. A. M.; de Sousa, E. H. S.; Campos, M. M.; Basso, L. A.; Santos, D. S.; Machado, P.; J. Braz. Chem. Soc. 2017, 28, 2028.

150. Rodrigues-Junior, V. S.; Machado, P.; Calixto, J. B.; Siqueira, J. M.; Andrade, E. L.; Bento, A. F.; Campos, M. M.; Basso, L. A.; Santos, D. S.; Regul. Toxicol. Pharmacol. 2017, 86, 11.

151. Rodrigues-Junior, V. S.; Cintra, L.; Machado, P.; Dadda, A.; Basso, L. A.; Mafra, A.; Campos, A. H.; Campos, M. M.; Santos, D. S.; Regul. Toxicol. Pharmacol. 2017, 90, 78.

152. Rodrigues, V. S.; dos Santos, A. A.; Villela, A. D.; Belardinelli, J. M.; Morbidoni, H. R.; Basso, L. A.; Campos, M. M.; Santos, D. S.; Int. J. Antimicrob. Agents 2014, 43, 82.

153. Rodrigues, V. S.; dos Santos, A.; Santos, A. J.; Schneider, C. Z.; Calixto, J. B.; Sousa, E. H. S.; Lopes, L. G. D.; Souto, A. A.; Basso, L. A.; Santos, D. S.; Campos, M. M.; Int. J. Antimicrob. Agents 2012, 40, 182.

154. Basso, L. A.; Schneider, C. Z.; dos Santos, A. J. A. B.; dos Santos, A. A.; Campos, M. M.; Souto, A. A.; Santos, D. S.; J. Braz. Chem. Soc. 2010, $21,1384$.

155. Oliveira, J. S.; de Sousa, E. H. S.; de Souza, O. N.; Moreira, I. S.; Santos, D. S.; Basso, L. A.; Curr. Pharm. Des. 2006, 12, 2409.

156. Abbadi, B. L.; Villela, A. D.; Rodrigues-Junior, V. S.; Subtil, F. T.; Dalberto, P. F.; Pinheiro, A. P. S.; Santos, D. S.; Machado, P.; Basso, L. A.; Bizarro, C. V.; Antimicrob. Agents Chemother. 2018, 62.

157. Abbadi, B. L.; Rodrigues-Junior, V. D. S.; Dadda, A. D. S.; Pissinate, K.; Villela, A. D.; Campos, M. M.; Lopes, L. G. F.; Bizarro, C. V.; Machado, P.; Sousa, E. H. S.; Basso, L. A.; Front. Microbiol. 2018, 9, 880.

158. Dadda, A. D. S.; Rodrigues-Junior, V. S.; Carreno, F.; Petersen, G. O.; Pinto, A. F. M.; Dalberto, P. F.; Sperotto, N. D. M.; Pissinate, K.; Bizarro, C. V.; Machado, P.; Campos, M. M.; Costa, T. D.; Santos, D. S.; Basso, L. A.; Eur. J. Pharm. Sci. 2018, 111, 393.

159. Rodrigues-Junior, V. S.; Villela, A. D.; Abbadi, B. L.; Sperotto, N. D. M.; Pissinate, K.; Picada, J. N.; Bondan da Silva, J.; Bizarro, C. V.; Machado, P.; Basso, L. A.; Regul. Toxicol. Pharmacol. 2019, 111, 104553. 